NBER WORKING PAPER SERIES

\title{
A SOLUTION TO THE DISCONNECT BETWEEN COUNTRY RISK AND BUSINESS
} CYCLE THEORIES

\author{
Enrique G. Mendoza \\ Vivian Z. Yue \\ Working Paper 13861 \\ http://www.nber.org/papers/w13861
NATIONAL BUREAU OF ECONOMIC RESEARCH
1050 Massachusetts Avenue
Cambridge, MA 02138
March 2008

We thank Cristina Arellano, Andy Atkeson, Fernando Broner, Jonathan Eaton, Jonathan Heathcote, Olivier Jeanne, Pat Kehoe, Tim Kehoe, Narayana Kocherlakota, Guido Lorenzoni, Andy Neumeyer, Fabrizio Perri, Victor Rios-Rull, Tom Sargent, Stephanie Schmitt-Grohe, Martin Uribe, and Mark Wright for helpful comments and suggestions. We also acknowledge comments by participants at seminars and conferences at Paris School of Economics, NYU, CUNY, the Federal Reserve Banks of Kansas City and Minneapolis, SUNY-Albany, Duke University, Univ. of Texas-Austin, Ohio State University, 2007 SED Annual Meeting, 2007 LACEA Annual Meeting, the CREI-CEPR 2007 Conference on Sovereign Risk, the X Workshop in International Economics and Finance at Di Tella University, the 2008 IEA World Congress and the 2008 NBER Summer Institute. The views expressed herein are those of the author(s) and do not necessarily reflect the views of the National Bureau of Economic Research.

NBER working papers are circulated for discussion and comment purposes. They have not been peerreviewed or been subject to the review by the NBER Board of Directors that accompanies official NBER publications.

(C) 2008 by Enrique G. Mendoza and Vivian Z. Yue. All rights reserved. Short sections of text, not to exceed two paragraphs, may be quoted without explicit permission provided that full credit, including (C) notice, is given to the source. 
A Solution to the Disconnect between Country Risk and Business Cycle Theories

Enrique G. Mendoza and Vivian Z. Yue

NBER Working Paper No. 13861

March 2008, Revised April 2010

JEL No. E32,E44,F32,F34

\section{$\underline{\text { ABSTRACT }}$}

We propose a model that solves the crucial disconnect between business cycle models that treat default risk as an exogenous interest rate on working capital, and sovereign default models that treat output fluctuations as an exogenous process with ad-hoc default costs. The model explains observed output dynamics around defaults, countercyclical spreads, high debt ratios, and key business cycle moments. Three features of the model are central for these results: working capital loans pay for imported inputs; default triggers an efficiency loss as imported inputs are replaced by imperfect domestic substitutes; and default on public and private foreign obligations occurs simultaneously.

Enrique G. Mendoza

Department of Economics

University of Maryland

College Park, MD 20742

and NBER

mendozae@econ.umd.edu

Vivian Z. Yue

Department of Economics

19 West 4th Street

New York University

New York, NY 10012

zy3@nyu.edu 


\section{Introduction}

Three key empirical regularities characterize the relationship between sovereign debt and economic activity in emerging economies:

(1) Output displays V-shaped dynamics around defaults. Arellano (2008) reports that in recent default episodes GDP deviations from trend were -14 percent in Argentina, -13 percent in Russia and -7 percent in Ecuador. Using quarterly data for 39 developing countries over the 1970-2005 period, Levy-Yeyati and Panizza (2006) show that the recessions associated with defaults are deep and generally hit their though when the defaults take place. Tomz and Wright (2007) study defaults from 1820 to 2004 and find the maximum default frequency when output is at least 7 percent below trend, although defaults can also occur without severe recessions.

(2) Interest rates on sovereign debt and GDP are negatively correlated. Neumeyer and Perri (2005) and Uribe and Yue (2006) report cyclical correlations between the two rates ranging from zero to -0.8 , with averages of -0.55 in Neumeyer and Perri and -0.42 in Uribe and Yue. ${ }^{1}$

(3) External debt as a share of GDP is high on average, and higher when countries default. Foreign debt was 1/3 of GDP on average over the 1998-2005 period for the group of emerging and developing countries as defined in IMF (2006). The highly indebted poor countries had the highest average debt ratio at about 100 percent of GDP, followed by the Eastern European and Western Hemisphere countries, with averages of about 50 and 40 percent of GDP respectively. Reinhart et al. (2003) report that the external debt ratio during default episodes averaged 71 percent of GDP for all developing country defaults in the 1824-1999 period. Recent defaults are in line with this estimate: Argentina defaulted in 2001 with a 64 percent debt ratio, and Ecuador and Russia defaulted in 1998 with debt ratios of 85 and 66 percent of GDP respectively.

Explanations of these stylized facts proposed in the International Macroeconomics literature suffer from a crucial disconnect between two important research programs: On one hand, quantitative models of business cycles in emerging economies explain countercyclical country interest rates by modeling the interest rate on sovereign debt as an exogenous interest rate that applies to foreign working capital loans obtained by firms. ${ }^{2}$ In these models, default is exogenous and hence facts (1) and (3) are left unexplained. On the other hand, quantitative models of sovereign default based on the classic setup of Eaton and Gersovitz (1981) generate countercyclical sovereign spreads by assuming that a sovereign borrower faces stochastic shocks to an exogenous output endowment with ad-hoc output costs of default. ${ }^{3}$ Since output is exogenous, these models cannot address fact (1) and they tend to do poorly

\footnotetext{
${ }^{1}$ Neumeyer and Perri used data for Argentina, Brazil, Korea, Mexico and the Philippines. Uribe and Yue added Ecuador, Peru and South Africa, but excluded Korea.

${ }^{2}$ See Neumeyer and Perri (2005), Uribe and Yue (2006) and Oviedo (2005).

${ }^{3}$ See, for example, Aguiar and Gopinath (2006), Arellano (2008), Bai and Zhang (2005) and Yue (2010).
} 
at explaining fact (3). In short, business cycle models of emerging economies cannot explain the default risk premia that drive their findings, and sovereign default models cannot explain the cyclical output dynamics that are critical for their results.

This paper offers a solution to the disconnect between country risk and business cycle theories by proposing a model of sovereign default with endogenous output fluctuations. The model features a transmission mechanism that links endogenous default risk with private economic activity via the financing cost of working capital used to pay for imported inputs. Imported inputs can be replaced with domestic inputs but these are imperfect substitutes in a standard Armington, or CES, aggregator, so that default causes an endogenous efficiency loss in production of final goods.

The contribution of this framework is that it provides a setup in which the equilibrium dynamics of output and default risk are determined jointly, and influence each other via the interaction between foreign lenders, the domestic sovereign borrower, domestic firms, and households. In particular, a fall in productivity increases the likelihood of default and hence sovereign spreads, and this in turn increases the firms' financing costs causing an efficiency loss that amplifies the negative effects of productivity shocks on output. This in turn feeds back into default incentives and sovereign spreads.

Quantitative analysis shows that the model can explain the three key stylized facts of sovereign debt. Moreover, the financial amplification mechanism amplifies the effect of TFP shocks on output by 80 percent when the economy defaults, and the model matches salient features of emerging markets business cycles such as the high variability of consumption, the countercyclical dynamics of net exports, and the correlation between output and default events.

These results hinge on three important features of the model: First, the assumption that producers of final goods obtain working capital loans from abroad to finance imports of intermediate goods. Second, the efficiency loss in final goods production that occurs when the country defaults, because of the loss of access to imported inputs for which domestic inputs are imperfect substitutes. Third, the assumption that the government can divert the private firms' repayment when it defaults on its own debt.

Existing empirical evidence is in line with the above features of our model. Amiti and Kronings (2007) and Halpern, Koren and Szeidl (2008) provide firm-level evidence of the imperfect substitutability between foreign and domestic inputs, and the associated TFP effect of changes in relative factor costs. In particular, they study the impact of reducing imported input tariffs on firm-level productivity using data for Indonesia and Hungary, respectively, and find that imperfect substitution of inputs accounts for the majority of effect of the tariff cuts on TFP. Reinhart and Rogoff (2010) and Reinhart (2010) show that there is a very tight connection between banking crises, with widespread defaults in the nonfinancial private sector, and sovereign defaults, and that private debts do become public debt after sovereign 
defaults.

The model's financial transmission mechanism operates as follows: Final goods producers use labor and an Armington aggregator of imported and domestic inputs as factors of production, with the two inputs as imperfect substitutes. A fraction of the cost of imported inputs is paid in advance using foreign working capital loans, while domestic inputs require domestic labor to be produced. Under these assumptions, the optimal input mix depends on the country interest rate (inclusive of default risk), which is also the financing cost of working capital, and on TFP. When the country has access to world financial markets, final goods producers use both imported and domestic inputs, and fluctuations in default risk affect the cost of working capital and thus induce "regular" fluctuations in factor demands and output. In contrast, when the country defaults, final goods producers switch to use domestic inputs only, because of the surge in the financing cost of imported inputs. This reduces production efficiency sharply because domestic inputs are imperfect substitutes for foreign inputs, and because in order to increase the supply of the former labor reallocates away from final goods production.

When the economy defaults, both the government and firms are excluded from world credit markets for some time, with an exogenous probability of re-entry as is common in quantitative studies of sovereign default. Since the probability of default depends on whether the sovereign's value of default is higher than that of repayment, there is feedback between the economic fluctuations induced by changes in default probabilities and country risk premia. In particular, rising country risk in the periods leading to a default causes a decline in economic activity as the firms' financing costs increase. In turn, the expectation of lower output at higher levels of country risk alters repayment incentives for the sovereign, affecting the equilibrium determination of default risk premia.

A central feature of our model is that the efficiency loss caused by sovereign default generates an endogenous output cost that is an increasing, strictly convex function of TFP. This differs sharply from the approaches followed to model output costs of default in the literature. In the literature, these costs are ad-hoc and modeled in one of two forms: First, as a fixed percent of output invariant to the realization of an exogenous endowment when a country defaults (see Aguiar and Gopinath (2006) and Yue (2010) for example). In this case, default is not too costly in a low endowment state relative to a high state, and hence average debt ratios are low when the models are calibrated to actual default frequencies. Second, the asymmetric formulation proposed by Arellano (2008). In this case, the percent output cost of default increases linearly if a defaulting country's endowment is higher than a certain threshold level, otherwise the percent output cost of default is zero. This asymmetric cost makes default more costly in good states, and thus yields higher debt ratios. However, the debt ratios in the calibrated models are still much lower than in the data, unless features like 
multiple maturities, dynamic renegotiation or political uncertainty are added. ${ }^{4}$

In contrast to the ad-hoc default costs typical in the default literature, the increasing, convex default cost of our model is a general equilibrium outcome driven by the effects of sovereign risk on private markets. This endogenous cost adds "state contingency" to the default option, allowing the model to support higher mean debt ratios at observed default frequencies. Our baseline calibration supports a mean debt-output ratio of about 24 percent, which is four times larger than in Arellano (2008). In addition, in our model outputs costs of default are always incurred at equilibrium, whereas with Arellano's asymmetric cost defaults tend to occur with the endowment lower than the threshold value, so output costs of default are zero at equilibrium. Moreover, in our setup, output itself falls sharply when the economy defaults, because the model's financial transmission mechanism amplifies the effects of TFP shocks on output. In contrast, in existing sovereign default models, large output drops can only result form large, exogenous endowment shocks.

The model requires foreign and domestic inputs to be imperfect substitutes in order to produce a default cost with the properties we described. ${ }^{5}$ The cost is higher and becomes a steeper function of TFP at lower Armington elasticities of substitution, because foreign and domestic inputs are less similar. The elasticity of labor supply also influences the output cost of default. In particular, the cost is larger the higher this elasticity, because default triggers a reduction in total labor usage. However, output costs of default, and the efficiency loss that drives them, are still present even if labor supply is inelastic. Final goods producers still have to shift from imported to domestic inputs, and labor still reallocates from final goods to intermediate goods production.

Since the sharp endogenous output drop that occurs in the model when the economy defaults reflects an efficiency loss, part of this output collapse shows as a fall in the Solow residual (i.e. the fraction of aggregate GDP not accounted for by capital and labor). This is consistent with the data from emerging markets crises showing that a large fraction of the observed output collapse is attributed to the Solow residual (Meza and Quintin (2006), Mendoza (2010)). Moreover, Benjamin and Meza (2007) show that in Korea's 1997 crisis, the productivity drop followed in part from a sectoral reallocation of labor.

The treatment of the financing cost of working capital in this paper differs from the treatment in Neumeyer and Perri (2005) and Uribe and Yue (2006), who treat this cost as

\footnotetext{
${ }^{4}$ Arellano (2008) obtained a mean debt-output ratio of 6 percent using her asymmetric cost. Aguiar and Gopinath (2006) obtained a mean debt ratio of 19 percent using the fixed percent cost, but at a default frequency of only 0.23 percent. Yue (2010) used the same cost in a model with renegotiation calibrated to observed default frequencies, and obtained a mean debt ratio of 9.7 percent. Studies that have obtained higher debt ratios with modifications of the Eaton-Gersovitz environment, but still assuming exogenous endowments, include: Cuadra and Sapriza (2008), D'Erasmo (2008), Bi (2008a) and (2008b), Chatterjee and Eyigungor (2008), Benjamin and Wright (2008), and Lizarazo (2005).

${ }^{5}$ If the inputs are perfect substitutes there is no output cost of default, because firms can shift inputs without affecting production and costs. If they are complements, production is either zero (with unitary elasticity of substitution) or not defined (with less-than-unitary elasticity) when the economy defaults and cannot access imported inputs.
} 
an exogenous variable calibrated to match the interest rate on sovereign debt. In contrast, in our setup both interest rates are driven by endogenous sovereign risk. In addition, in the Neumeyer-Perri and Uribe-Yue models, working capital loans pay the wages bill in full, while in our model firms use working capital to pay only for a small fraction of imported intermediate goods (about 1/10 in the benchmark calibration). This lower working capital requirement is desirable because, at standard labor income shares, working capital loans would need to be about $2 / 3$ rds of GDP to cover the wages bill, and this is difficult to reconcile with observed ratios of total bank credit to the private sector as a share of output in emerging economies, which hover around 50 percent (including all credit to households and firms at all maturities).

Our analysis is also related to the literature documenting explicit and implicit sanctions on trade flows and trade credit in response to sovereign defaults. Both are relevant for our analysis because the implications of our model are identical whether default triggers exclusion from trade credit or trade sanctions affecting imports of intermediate goods. Kaletsky (1985) argued that exclusion from trade credit might be the heaviest penalty that a defaulter faces. He documented the exclusion from trade credit experienced by the countries that defaulted in the 1980s, and showed estimates of short-term private credit nearly as large as unpaid interest in medium-term sovereign debt. More recently, Kohlscheen and O'Connell (2008) showed evidence of sharp declines in trade credit from commercial banks during default episodes. Rose (2005) conducted a cross-country analysis of trade flows and default, and found that default has a large, persistent negative effect on bilateral trade between creditor and debtor countries, and Martinez and Sandleris (2008) provided further empirical evidence on the association between sovereign defaults and the decline in trade.

The rest of the paper proceeds as follows: Section 2 presents the model. Section 3 examines the effects of interest rate changes on production and factor allocations in partial equilibrium. Section 4 explores the full model's quantitative implications for a benchmark calibration. Section 5 conducts sensitivity analysis. Section 6 concludes.

\section{A Model of Sovereign Default and Business Cycles}

We study a dynamic stochastic general equilibrium model of sovereign default and business cycles. There are four groups of agents in the model, three in the "domestic" small open economy (households, firms, and the sovereign government) and one abroad (foreign lenders). There are also two sets of producers in the domestic economy: a sector $f$ of final goods producers and a sector $m$ of intermediate goods producers.

\subsection{Households}


Households choose consumption and labor supply so as to maximize a standard time-separable utility function $E\left[\sum_{t=0}^{\infty} \beta^{t} u\left(c_{t}-g\left(L_{t}\right)\right)\right]$, where $0<\beta<1$ is the discount factor, and $c_{t}$ and $L_{t}$ denote consumption and labor supplied in period $t$ respectively. $u(\cdot)$ is the period utility function, which is continuous, strictly increasing, strictly concave, and satisfies the Inada conditions. Following Greenwood, Hercowitz and Huffman (1988), we remove the wealth effect on labor supply by specifying period utility as a function of consumption net of the disutility of labor $g\left(L_{t}\right)$, where $g(\cdot)$ is increasing, continuously differentiable and convex. This formulation of preferences plays an important role in allowing international real business cycle models to explain observed business cycle facts, and it also simplifies the "supply side" of the model.

Households take as given the wage rate $w_{t}$, profits paid by firms in the $f$ and $m$ sectors $\left(\pi_{t}^{f}, \pi_{t}^{m}\right)$ and government transfers $\left(T_{t}\right)$. Households do not borrow directly from abroad, but the government borrows, pays transfers, and makes default decisions internalizing their utility function. ${ }^{6}$ Consequently, the households' optimization problem reduces to the following static problem:

$$
\begin{aligned}
& \max _{c_{t}, L_{t}} E\left[\sum \beta^{t} u\left(c_{t}-g\left(L_{t}\right)\right)\right], \\
& \text { s.t. } \quad c_{t}=w_{t} L_{t}+\pi_{t}^{f}+\pi_{t}^{m}+T_{t} .
\end{aligned}
$$

The optimality condition for labor supply is:

$$
g^{\prime}\left(L_{t}\right)=w_{t}
$$

For purposes of the quantitative analysis, we define the labor disutility function in isoelastic form $g(L)=\frac{L^{\omega}}{\omega}$ with $\omega>1$. Hence, the Frisch elasticity of labor supply will be given by $1 /(\omega-1)$. The period utility function takes the standard constant-relative-risk-aversion form $u(c, L)=\frac{\left(c-L^{\omega} / \omega\right)^{1-\sigma}-1}{1-\sigma}$ with $\sigma>0$.

\subsection{Final Goods Producers}

Firms in the $f$ sector use two variable factors, labor $L_{t}^{f}$ and intermediate goods $M_{t}$, and a time-invariant capital stock $k .^{7}$ They face Markov TFP shocks $\varepsilon_{t}$, with the transition probability distribution function $\mu\left(\varepsilon_{t} \mid \varepsilon_{t-1}\right)$. The production function is Cobb-Douglas:

\footnotetext{
${ }^{6}$ This assumption is very common in the Eaton-Gersovitz class of models but it is not innocuous, because whether private foreign debt contracts are allowed, and whether they are enforceable vis-a-vis government external debt, affects the efficiency of the credit market equilibrium (see Wright (2006)).

${ }^{7}$ Sovereign debt models generally abstract from capital accumulation for simplicity. Adding capital makes the recursive contract with default option significantly harder to solve because it adds an additional endogenous state variable. Moreover, changes in the capital stock have been estimated to play a small role in output dynamics around financial crises (see Meza and Quintin (2006) and Mendoza (2007)).
} 


$$
y_{t}=\varepsilon_{t}\left(M\left(m_{t}^{d}, m_{t}^{*}\right)\right)^{\alpha_{M}}\left(L_{t}^{f}\right)^{\alpha_{L}} k^{\alpha_{k}}
$$

with $0<\alpha_{L}, \alpha_{M}, \alpha_{k}<1$ and $\alpha_{L}+\alpha_{M}+\alpha_{k}=1$.

The mix of intermediate goods used in the production of final goods is determined by a standard Armington aggregator of imported inputs $m_{t}^{*}$ and inputs produced at home $m_{t}^{d}$ :

$$
M\left(m_{t}^{d}, m_{t}^{*}\right)=\left(\lambda\left(m_{t}^{d}\right)^{\mu}+(1-\lambda)\left(m_{t}^{*}\right)^{\mu}\right)^{\frac{1}{\mu}}
$$

The elasticity of substitution between $m_{t}^{*}$ and $m_{t}^{d}$ is equal to $|1 /(\mu-1)|$ and $\lambda$ is the Armington weight of domestic inputs. The typical parameter restrictions on the Armington aggregator are $-\infty \leq \mu \leq 1,0 \leq \lambda \leq 1$. In our model, however, we will show later that $0<\mu<1$ is necessary in order to support equilibria in which $y_{t}$ at default is well defined and the output cost of default increases with $\varepsilon$.

Imported inputs are sold in a competitive world market at the exogenous price $p_{m}^{*}$ relative to the final good, which is used as numeraire. ${ }^{8}$ A fraction $\theta$ of the cost of these inputs needs to be paid in advance using working capital loans $\kappa_{t}$. These are intraperiod loans repaid at the end of the period that are offered by foreign creditors at the interest rate $r_{t}$. This interest rate is linked to the sovereign interest rate at equilibrium, as shown in the next section. Working capital loans satisfy the standard payment-in-advance condition: ${ }^{9}$

$$
\frac{\kappa_{t}}{1+r_{t}} \geq \theta p_{m}^{*} m_{t}^{*}
$$

Profit-maximizing producers of final goods choose $\kappa_{t}$ so that this condition holds with equality. Domestic inputs do not require working capital financing, but this assumption is just for simplicity, the key element for the analysis is that at high levels of country risk (including periods without access to foreign credit markets) the financing cost of foreign inputs is higher than that of domestic inputs.

The optimization problem of final goods producers can be expressed using a static payoff, so that these producers choose factor demands in order to maximize date- $t$ profits taking $w_{t}$, $r_{t}, p_{m}^{*}$, and $p_{t}^{m}$ (the endogenous price of domestic inputs relative to final goods) as given. Date- $t$ Profits are:

$$
\pi_{t}^{f}=\varepsilon_{t}\left(M\left(m_{t}^{d}, m_{t}^{*}\right)\right)^{\alpha_{M}}\left(L_{t}^{f}\right)^{\alpha_{L}} k^{\alpha_{k}}-p_{m}^{*}\left(1+\theta r_{t}\right) m_{t}^{*}-p_{t}^{m} m_{t}^{d}-w_{t} L_{t}^{f},
$$

We can simplify the problem in this way because working capital is modeled as an intra-period

\footnotetext{
${ }^{8}$ This price can also be modeled as a terms-of-trade shock with a given stochastic process.

${ }^{9}$ We model the working capital as an intra-period loan, as in the classic work of Fuerst (1992), and Christiano and Eichenbaum (1992), Neumeyer and Perri (2005), Mendoza (2010). Similar to Uribe and Yue (2006), a fully specified firm optimization problem shows that the rate determining the cost of intra-period working capital loans is the same as the between period rate on one-period loans. See Appendix.
} 
loan, as in the classic setup of Fuerst (1992), which has been used extensively in business cycle models of emerging economies (see Neumeyer and Perri (2005), Uribe and Yue (2006), and Mendoza (2010)). Following Uribe and Yue, we can derive the above static formulation of profits from a standard problem maximizing the present value of dividends subject to the working capital constraint. This also establishes two important results, which can be misinterpreted as assumptions if one considers only the static definition of profits: First, the interest rate determining the cost of intra-period working capital loans is the same as the between-period rate on one-period loans. Second, since factor demands are characterized by standard conditions equating marginal products to marginal costs (see below), firms do not accumulate precautionary asset holdings to self insure against changes in factor costs.

The first-order conditions of the optimization problem of final goods producers are:

$$
\begin{aligned}
\alpha_{M} \varepsilon_{t} k^{\alpha_{k}}\left(M\left(m_{t}^{d}, m_{t}^{*}\right)\right)^{\alpha_{M}-\mu}\left(L_{t}^{f}\right)^{\alpha_{L}}(1-\lambda)\left(m_{t}^{*}\right)^{\mu-1} & =p_{m}^{*}\left(1+\theta r_{t}\right) \\
\alpha_{M} \varepsilon_{t} k^{\alpha_{k}}\left(M\left(m_{t}^{d}, m_{t}^{*}\right)\right)^{\alpha_{M}-\mu}\left(L_{t}^{f}\right)^{\alpha_{L}} \lambda\left(m_{t}^{d}\right)^{\mu-1} & =p_{t}^{m} \\
\alpha_{L} \varepsilon_{t} k^{\alpha_{k}} M_{t}^{\alpha_{M}}\left(L_{t}^{f}\right)^{\alpha_{L}-1} & =w_{t} .
\end{aligned}
$$

\subsection{Intermediate Goods Producers}

Producers in the $m$ sector use labor $L_{t}^{m}$ and operate with a production function given by $A\left(L_{t}^{m}\right)^{\gamma}$, with $0 \leq \gamma \leq 1$ and $A>0$. A represents both the role of a fixed factor and an invariant state of TFP in the $m$ sector. Given $p_{t}^{m}$ and $w_{t}$, the profit maximization problem of intermediate goods firms is:

$$
\max _{L_{t}^{m}} \pi_{t}^{m}=p_{t}^{m} A\left(L_{t}^{m}\right)^{\gamma}-w_{t} L_{t}^{m}
$$

Their optimal labor demand satisfies this standard condition:

$$
\gamma p_{t}^{m} A\left(L_{t}^{m}\right)^{\gamma-1}=w_{t}
$$

\subsection{Competitive Equilibrium of the Private Sector}

Definition 1 A competitive equilibrium for the private sector of the economy is given by sequences of allocations $\left[c_{t}, L_{t}, L_{t}^{f}, L_{t}^{m}, m_{t}^{d}, m_{t}^{*}, \kappa_{t}\right]_{t=0}^{\infty}$ and prices $\left[w_{t}, p_{t}^{m}, \pi_{t}^{f}, \pi_{t}^{m}\right]_{t=0}^{\infty}$ such that given interest rates $\left[r_{t}\right]_{t=0}^{\infty}$, government transfers $\left[T_{t}\right]_{t=0}^{\infty}$ and TFP realizations $\left[\varepsilon_{t}\right]_{t=0}^{\infty}$ :

1. $\left[c_{t}, L_{t}\right]_{t=0}^{\infty}$ solve the households' utility maximization problem.

2. $\left[L_{t}^{f}, m_{t}^{d}, m_{t}^{*}, \kappa_{t}\right]_{t=0}^{\infty}$ solve the profit maximization problem of sector $f$ producers.

3. $\left[L_{t}^{m}\right]_{t=0}^{\infty}$ solve the profit maximization problem of sector $m$ producers. 
4. The market-clearing conditions for the labor market $\left(L_{t}^{f}+L_{t}^{m}=L_{t}\right)$ and the domestic intermediate goods market $\left(A\left(L_{t}^{m}\right)^{\gamma}=m_{t}^{d}\right)$ hold.

A key constraint on the problem of the sovereign borrower making the default decision will be that private-sector allocations must be a competitive equilibrium. Since the government's problem and the equilibrium of the credit market will be characterized in recursive form as functions defined in the state space domain, it is useful to also characterize the above competitive equilibrium in terms of functions of state variables, and to distinguish private sector allocations in states in which the economy has credit market access from those in which it does not.

If sector $f$ has access to credit markets, the private sector equilibrium can be represented by the set of functions $\left[m^{*}(r, \varepsilon), m^{d}(r, \varepsilon), L^{f}(r, \varepsilon), L^{m}(r, \varepsilon), L(r, \varepsilon), p^{m}(r, \varepsilon), w(r, \varepsilon), \kappa(r, \varepsilon)\right]$ that solve the following nonlinear system of equations for a given pair $(r, \varepsilon)$ :

$$
\begin{aligned}
\alpha_{M} \varepsilon k^{\alpha_{k}}\left(M\left(m^{d}, m^{*}\right)\right)^{\alpha_{M}-\mu}\left(L^{f}\right)^{\alpha_{L}}(1-\lambda)\left(m^{*}\right)^{\mu-1} & =p_{m}^{*}(1+\theta r) \\
\alpha_{M} \varepsilon k^{\alpha_{k}}\left(M\left(m^{d}, m^{*}\right)\right)^{\alpha_{M}-\mu}\left(L^{f}\right)^{\alpha_{L}} \lambda\left(m^{d}\right)^{\mu-1} & =p^{m} \\
\alpha_{L} \varepsilon k^{\alpha_{k}}\left(M\left(m^{d}, m^{*}\right)\right)^{\alpha_{M}}\left(L^{f}\right)^{\alpha_{L}-1} & =w \\
\gamma p^{m} A\left(L^{m}\right)^{\gamma-1} & =w \\
g^{\prime}(L) & =w \\
L^{f}+L^{m} & =L \\
A\left(L^{m}\right)^{\gamma} & =m^{d} \\
\kappa(r, \varepsilon) & =\theta p_{m}^{*} m^{*}(1+r) .
\end{aligned}
$$

During periods of exclusion from world credit markets, the private competitive equilibrium is the limiting case of the above nonlinear system as $r \rightarrow \infty$. Since sector $f$ does not have access to foreign working capital financing, it uses only domestic inputs. Assuming $0<\mu<1$, the nonlinear system has the following closed-form solutions expressed as functions of $\varepsilon$ :

$$
\begin{aligned}
\tilde{L}(\varepsilon) & =\left[\left(\alpha_{L}+\gamma \alpha_{m}\right) \varepsilon k^{\alpha_{k}} \eta^{\frac{\alpha_{m}}{\mu}} A^{\alpha_{m}}\left(z_{L_{m}}\right)^{\alpha_{m} \gamma}\left(z_{L_{f}}\right)^{\alpha_{L}}\right]^{1 /\left(\omega-\alpha_{L}-\alpha_{m} \gamma\right)} \\
\tilde{L}^{f}(\varepsilon) & =z_{L_{f}} \tilde{L}(\varepsilon) \\
\tilde{L}^{m}(\varepsilon) & =z_{L_{m}} \tilde{L}(\varepsilon) \\
\tilde{m}(\varepsilon) & =A\left(\tilde{L}^{m}(\varepsilon)\right)^{\gamma} \\
\tilde{p}^{m}(\varepsilon) & =\alpha_{m} \eta^{\frac{\alpha_{m}}{\mu}} \varepsilon(\tilde{m}(\varepsilon))^{\alpha_{m}-1}\left(\tilde{L}^{f}(\varepsilon)\right)^{\alpha_{L}} k^{\alpha_{k}},
\end{aligned}
$$

where $z_{L_{m}}=\gamma \alpha_{m} /\left(\gamma \alpha_{m}+\alpha_{L}\right)$ and $z_{L_{f}}=\alpha_{L} /\left(\gamma \alpha_{m}+\alpha_{L}\right)$.

Conditions (13)-(25) are crucial because they drive the effects of fluctuations in TFP and 
interest rates on production and factor allocations before, during, and after default episodes. We study these effects in detail in Section 3.

Using conditions (13)-(25), it is also straightforward to explain why foreign and domestic inputs need to be imperfect substitutes (i.e. $0<\mu<1$ ). If $\mu=1$, there is no output cost of default because the two inputs are perfect substitutes, and hence there is no efficiency loss in changing one input for the other. If $\mu \leq 0$, the two inputs are complements and there are two outcomes: If $\mu=0$ (the unitary elasticity case), default implies $m_{t}^{*}=0$ and $y_{t}=0$, and the output cost of default is 100 percent for any value of $\varepsilon_{t}$. If $\mu<0$, strict complementarity implies that with $m_{t}^{*}=0$ the value of $y_{t}$ is undefined.

Given sectoral production and factor allocations, we apply standard National Accounts definitions to compute GDP as gross production of final goods minus the cost of imported inputs at constant prices, $g d p_{t} \equiv y_{t}-p_{m}^{*}\left(1+\theta r_{t}\right) m_{t}^{*} \cdot{ }^{10}$ Using the optimality conditions of the $f$ and $m$ sectors, we can rewrite GDP as $g d p=\left(1-\alpha_{M}\right) \varepsilon_{t}\left(M_{t}\right)^{\alpha_{M}}\left(L_{t}^{f}\right)^{\alpha_{L}} k^{\alpha_{k}}+p_{t}^{m} A\left(L_{t}^{m}\right)^{\gamma}$. The first and second terms in the right-hand-side of this expression represent value added in the $f$ and $m$ sectors respectively. Note that given the CES formulation of $M_{t}$, the firms' optimality conditions imply that $p_{m}^{*}\left(1+\theta r_{t}\right) m_{t}^{*}=\alpha_{M} \varepsilon_{t}\left(M_{t}\right)^{\alpha_{M}}\left(L_{t}^{f}\right)^{\alpha_{L}} k^{\alpha_{k}}-p_{t}^{m} m_{t}^{d}$. Thus, the cost of imported inputs valued at constant prices equals the fraction $\alpha_{M}$ of final goods production minus the cost of domestic inputs, but with the latter valued at their equilibrium time-varying price.

\subsection{The Sovereign Government}

The sovereign government trades with foreign lenders one-period, zero-coupon discount bonds, so markets of contingent claims are incomplete. The face value of these bonds specifies the amount to be repaid next period, $b_{t+1}$. When the country purchases bonds $b_{t+1}>0$, and when it borrows $b_{t+1}<0$. The set of bond face values is $B=\left[b_{\min }, b_{\max }\right] \subset R$, where $b_{\min } \leq 0 \leq b_{\max }$. We set the lower bound $b_{\min }>-\frac{\bar{y}}{r}$, which is the largest debt that the country could repay with full commitment. The upper bound $b_{\max }$ is the highest level of assets that the country may accumulate. ${ }^{11}$

The sovereign cannot commit to repay its debt. As in the Eaton-Gersovitz model, we assume that when the country defaults it does not repay at date $t$ and the punishment is exclusion from the world credit market in the same period. The country re-enters the credit market with an exogenous probability $\eta$, and when it does it starts with a fresh record and zero debt. ${ }^{12}$ Also as in the Eaton-Gersovitz setup, the country cannot hold positive international

\footnotetext{
${ }^{10}$ This definition matches the methodology followed in most emerging economies, which compute real GDP at constant prices of a base year using Laspeyres indexes. Note that this is also the case in the model because $p_{m}^{*}$ is constant.

${ }^{11} b_{\max }$ exists when the interest rates on a country's saving are sufficiently small compared to the discount factor, which is satisfied in our paper since $\left(1+r^{*}\right) \beta<1$.

${ }^{12}$ We asbtract from debt renegotiation. See Yue (2010), Bi (2008b) and Benjamin and Wright (2008) for quantitative studies of sovereign default with renegotiation.
} 
assets during the exclusion period, otherwise the model cannot support equilibria with debt.

We add to the Eaton-Gersovitz setup an explicit link between default risk and private financing costs. This is done by assuming that a defaulting sovereign can divert the repayment of the firms' working capital loans to foreign lenders. Hence, both firms and government default together. As explained in the introduction, this is very much in line with the historical evidence documented by Reinhart and Rogoff (2010) and Reinhart (2010). We also provide empirical evidence later in this Section showing the tight link between private and public borrowing costs.

The sovereign government solves a problem akin to a Ramsey problem. ${ }^{13}$ It chooses a debt policy (amounts and default or repayment) that maximizes the households' welfare subject to the constraints that: (a) the private sector allocations must be a competitive equilibrium; and (b) the government budget constraint must hold. The state variables are the bond position, working capital loans as of the end of last period, and the state of TFP, denoted by the triplet $\left(b_{t}, \kappa_{t-1}, \varepsilon_{t}\right)$. The price of sovereign bonds is given by the bond pricing function $q_{t}\left(b_{t+1}, \varepsilon_{t}\right)$. Since at equilibrium the default risk premium on sovereign debt will be the same as on working capital loans, it follows that the interest rate on working capital is a function of $q_{t}\left(b_{t+1}, \varepsilon_{t}\right)$. Hence, the recursive functions that represent the competitive equilibrium of the private sector when the economy has access to world credit markets can be rewritten as $\kappa\left(q_{t}\left(b_{t+1}, \varepsilon_{t}\right), \varepsilon_{t}\right), M\left(q_{t}\left(b_{t+1}, \varepsilon_{t}\right), \varepsilon_{t}\right), m^{*}\left(q_{t}\left(b_{t+1}, \varepsilon_{t}\right), \varepsilon_{t}\right), m^{d}\left(q_{t}\left(b_{t+1}, \varepsilon_{t}\right), \varepsilon_{t}\right)$, $L^{f}\left(q_{t}\left(b_{t+1}, \varepsilon_{t}\right), \varepsilon_{t}\right), L^{m}\left(q_{t}\left(b_{t+1}, \varepsilon_{t}\right), \varepsilon_{t}\right)$, and $L\left(q_{t}\left(b_{t+1}, \varepsilon_{t}\right), \varepsilon_{t}\right)$.

The recursive optimization problem of the government is summarized by the following value function:

$$
V\left(b_{t}, \kappa_{t-1}, \varepsilon_{t}\right)=\max \left\{v^{n d}\left(b_{t}, \varepsilon_{t}\right), v^{d}\left(\kappa_{t-1,} \varepsilon_{t}\right)\right\} .
$$

If the country has access to the world credit market at date $t$, the value function is the maximum of the value of continuing in the credit relationship with foreign lenders (i.e., "no default"), $v^{n d}\left(b_{t}, \varepsilon_{t}\right)$, and the value of default, $v^{d}\left(\kappa_{\left.t-1, \varepsilon_{t}\right)}\right.$. If $b_{t} \geq 0$, the value function is simply $v^{n d}\left(b_{t}, \varepsilon_{t}\right)$ because in this case the economy uses the credit market to save, receiving a return equal to the world's risk free rate $r^{*}$.

The continuation value is defined as follows:

$$
v^{n d}\left(b_{t}, \varepsilon_{t}\right)=\max _{c_{t}, b_{t+1}}\left\{\begin{array}{c}
u\left(c_{t}-g\left(L\left(q_{t}\left(b_{t+1}, \varepsilon_{t}\right), \varepsilon_{t}\right)\right)\right) \\
+\beta E\left[V\left(b_{t+1}, \kappa\left(q_{t}\left(b_{t+1}, \varepsilon_{t}\right), \varepsilon_{t}\right), \varepsilon_{t+1}\right)\right]
\end{array}\right\},
$$

\footnotetext{
${ }^{13}$ See Cuadra and Sapriza (2007) for an analysis of optimal fiscal policy as a Ramsey problem in the presence of sovereign default in an endowment economy.
} 
subject to

$$
\begin{aligned}
c_{t}+q_{t}\left(b_{t+1}, \varepsilon_{t}\right) b_{t+1}-b_{t} \leq \varepsilon_{t} f\left(M\left(q_{t}\left(b_{t+1}, \varepsilon_{t}\right), \varepsilon_{t}\right), L^{f}\left(q_{t}\left(b_{t+1}, \varepsilon_{t}\right), \varepsilon_{t}\right), k\right) \\
-m^{*}\left(q_{t}\left(b_{t+1}, \varepsilon_{t}\right), \varepsilon_{t}\right) p_{m}^{*}\left(1+\frac{\theta}{q_{t}\left(b_{t+1}, \varepsilon_{t}\right)}-\theta\right)
\end{aligned}
$$

where $f(\cdot)=M^{\alpha_{M}}\left(L_{t}^{f}\right)^{\alpha_{L}} k^{\alpha_{k}}$. The constraint of this problem is the resource constraint of the economy at a competitive equilibrium. The left-hand-side is the sum of consumption and net exports, and the right-hand-side is GDP. This constraint is obtained by combining the households' budget constraint (2) with the government budget constraint, $T_{t}=b_{t}-$ $q_{t}\left(b_{t+1}, \varepsilon_{t}\right) b_{t+1}$.

The resource constraint (28) captures three important features of the model: First, the government internalizes how interest rates and working capital affect the competitive equilibrium allocations of output and factor demands. Second, the government also internalizes the households' desire to smooth consumption, and hence transfers to them an amount equal to the negative of the balance of trade (i.e. the flow of resources private agents need to finance the gap between GDP and consumption). Third, the working capital loans $\kappa_{t-1}$ and $\kappa_{t}$ do not enter explicitly in the continuation value or in the resource constraint but they are relevant state variables, because the amount of working capital loans taken by final goods producers at date $t$ affects the sovereign's incentive to default at $t+1$, as explained below.

The value of default is:

$$
v^{d}\left(\kappa_{t-1}, \varepsilon_{t}\right)=\max _{c_{t}}\left\{\begin{array}{r}
u\left(c_{t}-g\left(\tilde{L}\left(\varepsilon_{t}\right)\right)\right) \\
+\beta(1-\eta) E v^{d}\left(0, \varepsilon_{t+1}\right)+\beta \eta E V\left(0,0, \varepsilon_{t+1}\right)
\end{array}\right\},
$$

subject to:

$$
c_{t}=\varepsilon_{t} f\left(\lambda^{\frac{1}{\mu}} \tilde{m}(\varepsilon), \tilde{L}^{f}(\varepsilon), k\right)+\kappa_{t-1} .
$$

Note that $v^{d}\left(\kappa_{t-1}, \varepsilon_{t}\right)$ takes into account the fact that in case of default at date $t$, the country has no access to financial markets this period, and hence the country consumes the total income given by the resource constraint in the default scenario. In this case, since firms cannot borrow to finance purchases of imported inputs, $\tilde{m}(\varepsilon), \tilde{L}(\varepsilon)$ and $\tilde{L}^{f}(\varepsilon)$ are competitive equilibrium allocations that correspond to the case when the $f$ sector operates with domestic inputs only (in this case, $M=\lambda^{\frac{1}{\mu}} \tilde{m}(\varepsilon)$ ). Moreover, because the defaulting government diverts the repayment of last period's working capital loans, total household income includes government transfers equal to the appropriated repayment $\kappa_{t-1}$ (i.e., on the date of default, the government budget constraint is $T_{t}=\kappa_{t-1}$ ). The value of default at $t$ also takes into account that at $t+1$ the economy may re-enter world capital markets with probability $\eta$ and associated value $V\left(0,0, \varepsilon_{t+1}\right)$, or remain in financial autarky with probability $1-\eta$ and associated value $v^{d}\left(0, \varepsilon_{t+1}\right)$. 
For a debt position $b_{t}<0$ and given a level of working capital $\kappa_{t-1}$, default is optimal for the set of realizations of $\varepsilon_{t}$ for which $v^{d}\left(\kappa_{t-1}, \varepsilon_{t}\right)$ is at least as high as $v^{n d}\left(b_{t}, \varepsilon_{t}\right)$ :

$$
D\left(b_{t}, \kappa_{t-1}\right)=\left\{\varepsilon_{t}: v^{n d}\left(b_{t}, \varepsilon_{t}\right) \leq v^{d}\left(\kappa_{t-1}, \varepsilon_{t}\right)\right\}
$$

It is critical to note that this default set has a different specification than in the typical Eaton-Gersovitz model (see Arellano (2008)), because the state of working capital affects the gap between the values of default and repayment. This results in a two-dimensional default set that depends on $b_{t}$ and $\kappa_{t-1}$, instead of just $b_{t}$.

Despite the fact that the default set depends on $\kappa_{t-1}$, the probability of default remains a function of $b_{t+1}$ and $\varepsilon_{t}$ only. This is because the $f$ sector's optimality conditions imply that the next period's working capital loan $\kappa_{t}$ depends on $\varepsilon_{t}$ and the interest rate, which is a function of $b_{t+1}$ and $\varepsilon_{t}$. Thus the probability of default at $t+1$ perceived as of date $t$ for a country with a productivity $\varepsilon_{t}$ and debt $b_{t+1}, p_{t}\left(b_{t+1}, \varepsilon_{t}\right)$, can be induced from the default set, the decision rule for working capital, and the transition probability function of productivity shocks $\mu\left(\varepsilon_{t+1} \mid \varepsilon_{t}\right)$ as follows:

$$
p_{t}\left(b_{t+1}, \varepsilon_{t}\right)=\int_{D\left(b_{t+1}, \kappa_{t}\right)} d \mu\left(\varepsilon_{t+1} \mid \varepsilon_{t}\right), \text { where } \kappa_{t}=\kappa\left(q_{t}\left(b_{t+1}, \varepsilon_{t}\right), \varepsilon_{t}\right) .
$$

The economy is considered to be in financial autarky when it has been in default for at least one period and remains without access to world credit markets as of date $t$.The optimization problem of the sovereign is the same as the problem in the default period but evaluated at $\kappa_{t-1}=0$ (i.e. $v^{d}\left(\varepsilon_{t}, 0\right)$ ). This is the case because we assume that while in financial autarky the economy cannot build up its own stock of savings to supply working capital loans to firms, which could be used to purchase imported inputs. Alternatively, we can assume that the default punishment includes exclusion from both world capital markets and the world market of intermediate goods. Kaletsky (1985) argues that trade sanctions do play a role in actual default events.

The model preserves a standard feature of the Eaton-Gersovitz model: Given $\varepsilon_{t}$, the value of defaulting is independent of the level of debt, while the value of not defaulting increases with $b_{t+1}$, and consequently the default set and the equilibrium default probability grow with the country's debt. The following theorem formalizes this result:

Theorem 1 Given a productivity shock $\varepsilon$ and level of working capital loan $\kappa$, for $b^{0}<b^{1} \leq 0$, if default is optimal for $b^{1}$, then default is also optimal for $b^{0}$. That is $D\left(b^{1}, \kappa\right) \subseteq D\left(b^{0}, \kappa\right)$. The country agent's probability of default in equilibrium satisfies $p^{*}\left(b^{0}, \varepsilon\right) \geq p^{*}\left(b^{1}, \varepsilon\right)$.

Proof. See Appendix. 


\subsection{Foreign Lenders}

International creditors are risk-neutral and have complete information. They invest in sovereign bonds and in private working capital loans. Foreign lenders behave competitively and face an opportunity cost of funds equal to the world risk-free interest rate. Competition implies that they expect zero profits at equilibrium, and that the returns on sovereign debt and the world's risk-free asset are fully arbitraged:

$$
q_{t}\left(b_{t+1}, \varepsilon_{t}\right)=\left\{\begin{array}{cc}
\frac{1}{1+r^{*}} & \text { if } b_{t+1} \geq 0 \\
\frac{\left[1-p_{t}\left(b_{t+1}, \varepsilon_{t}\right)\right]}{1+r^{*}} & \text { if } b_{t+1}<0
\end{array} .\right.
$$

This condition implies that at equilibrium bond prices depend on the risk of default. For a high level of debt, the default probability is higher. Therefore, equilibrium bond prices decrease with indebtedness. This result, formalized in Theorem 2 below, is again in line with the Eaton-Gersovitz model and is also consistent with the empirical evidence documented by Edwards (1984).

Theorem 2 Given a productivity shock $\varepsilon$ and level of working capital loan $\kappa$, for $b^{0}<b^{1} \leq 0$, the equilibrium bond price satisfies $q^{*}\left(b^{0}, \varepsilon\right) \leq q^{*}\left(b^{1}, \varepsilon\right)$.

Proof. See Appendix.

The returns on sovereign bonds and working capital loans are also fully arbitraged. Because the sovereign government diverts the repayment of working capital loans when it defaults, foreign lenders assign the same risk of default to private working capital loans as to sovereign debt, and hence the no-arbitrage condition between sovereign lending and working capital loans implies:

$$
r_{t}\left(b_{t+1}, \varepsilon_{t}\right)=\frac{1}{q_{t}\left(b_{t+1}, \varepsilon_{t}\right)}-1 \text {, if } \kappa_{t}>0 .
$$

This arbitrage result raises a key empirical question: Are the interest rates faced by sovereign governments and private firms in emerging economies closely related?

Answering this question in full is beyond the scope of this paper, but we do provide evidence suggesting that corporate and sovereign interest rates tend to move together. To study this issue, we constructed a measure of firm-level effective interest rates as the ratio of a firm's total debt service divided by its total debt obligations using the Worldscope database. We then constructed country aggregates by computing the median across firms. Table 1 reports these estimates of corporate interest rates together with the standard EMBI+ measure of interest rates on sovereign debt and the correlations between the two.

Table 1 shows that the two interest rates are positively correlated in most countries, with a median correlation of 0.7 , and in some countries the relationship is very strong (see Figure 1). ${ }^{14}$

\footnotetext{
${ }^{14}$ Arellano and Kocherlakota (2007) and Agca and Celasun (2009) provide further empirical evidence of the
} 
Table 1: Sovereign and Corporate Interest Rates

\begin{tabular}{lccc}
\hline \hline Country & Sovereign Interest Rates & Median Firm Interest Rates & Correlation \\
\hline Argentina & 13.32 & 10.66 & 0.87 \\
Brazil & 12.67 & 24.60 & 0.14 \\
Chile & 5.81 & 7.95 & 0.72 \\
China & 6.11 & 5.89 & 0.52 \\
Colombia & 9.48 & 19.27 & 0.86 \\
Egypt & 5.94 & 8.62 & 0.58 \\
Malaysia & 5.16 & 6.56 & 0.96 \\
Mexico & 9.40 & 11.84 & 0.74 \\
Morocco & 9.78 & 13.66 & 0.32 \\
Pakistan & 9.71 & 12.13 & 0.84 \\
Peru & 9.23 & 11.42 & 0.72 \\
Philippines & 8.78 & 9.27 & 0.34 \\
Poland & 7.10 & 24.27 & 0.62 \\
Russia & 15.69 & 11.86 & -0.21 \\
South Africa & 5.34 & 15.19 & 0.68 \\
Thailand & 6.15 & 7.30 & 0.94 \\
Turkey & 9.80 & 29.26 & 0.88 \\
Venezuela & 14.05 & 19.64 & 0.16 \\
\hline \hline
\end{tabular}

The table also shows that the effective financing cost of firms is generally higher than the sovereign interest rates. This fact indicates that the common conjecture that firms (particularly the large corporations covered in our data) may pay lower rates than governments with default risk is incorrect.

There is also strong historical evidence in favor of the assumption driving the arbitrage of private and government interest rates in the model, namely that the government diverts the repayment of the firms' foreign obligations. As noted earlier, this is documented in the comprehensive studies by Reinhart and Rogoff (2010) and Reinhart (2010). In particular, it is common for governments to take over the foreign obligations of the corporate sector in actual default episodes, particularly when a domestic banking crisis precedes sovereign default, which is a common occurrence. ${ }^{15}$

positive relationship between private domestic lending rates and sovereign spreads.

${ }^{15}$ Arteta and Hale (2007) and Kohlscheen and O'Connell (2008) provide further evidence of significant adverse effects of sovereign default on private access to foreign credit. Arteta and Hale show that there are strong, systematic negative effects on private corporate bond issuance during and after default episodes. Kohlscheen and O'Connell document that the volume of trade credit provided by commercial banks falls sharply when countries default. The median drops in trade credit are about 35 and 51 percent two and four years after default events respectively. 

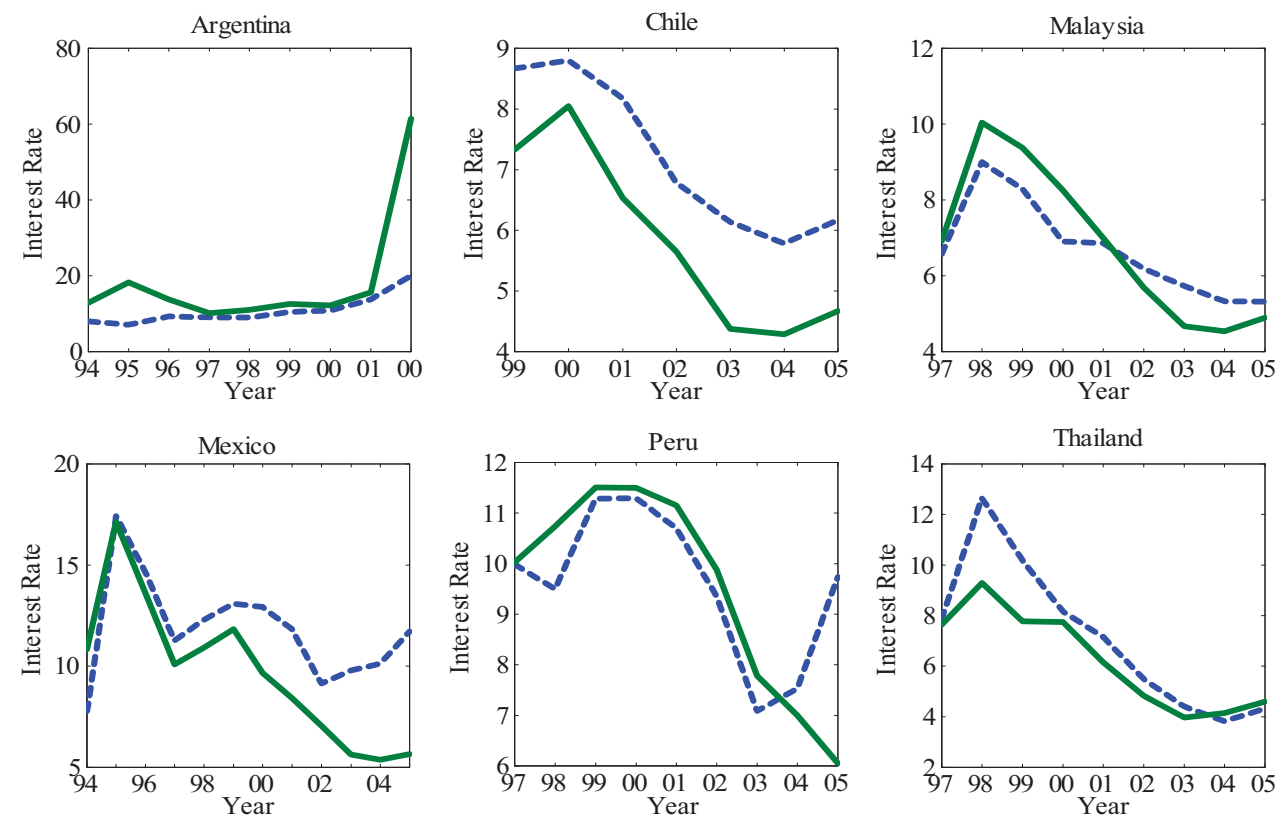

Sovereign Bond Interest Rates - - - Median Firm Financing Cost

Figure 1: Sovereign Bond Interest Rates and Median Firm Financing Costs

The following quote by the IMF Historian explains the mechanism by which the government took over corporate external debt in Mexico's 1982-83 default, and notes that arrangements of this type have been commonly used since then: "A simmering concern among Mexico's commercial bank creditors was the handling of private sector debts, a substantial portion of which was in arrears... the FICORCA scheme provided for firms to pay dollardenominated commercial debts in pesos to the central bank....Between March and November 1983, close to $\$ 12$ billion in private sector debts were rescheduled under this program... FICORCA then became the prototype for similar schemes elsewhere." (Boughton (2001), Ch. 9, pp. 360-361)

\subsection{Recursive equilibrium}

Definition 2 The model's recursive equilibrium is given by (i) a decision rule $b_{t+1}\left(b_{t}, \kappa_{t-1}, \varepsilon_{t}\right)$ for the sovereign government with associated value function $V\left(b_{t}, \kappa_{t-1}, \varepsilon_{t}\right)$, consumption and transfers rules $c\left(b_{t}, \kappa_{t-1}, \varepsilon_{t}\right)$ and $T\left(b_{t}, \kappa_{t-1}, \varepsilon_{t}\right)$, default set $D\left(b_{t}, \kappa_{t-1}\right)$ and default probabilities $p^{*}\left(b_{t+1}, \varepsilon_{t}\right)$; and (ii) an equilibrium pricing function for sovereign bonds $q^{*}\left(b_{t+1}, \varepsilon_{t}\right)$ such that:

1. Given $q^{*}\left(b_{t+1}, \varepsilon_{t}\right)$, the decision rule $b_{t+1}\left(b_{t}, \kappa_{t-1}, \varepsilon_{t}\right)$ solves the recursive maximization problem of the sovereign government (26).

2. The consumption plan $c\left(b_{t}, \kappa_{t-1}, \varepsilon_{t}\right)$ satisfies the resource constraint of the economy

3. The transfers policy $T\left(b_{t}, \kappa_{t-1}, \varepsilon_{t}\right)$ satisfies the government budget constraint. 
4. Given $D\left(b_{t}, \kappa_{t-1}\right)$ and $p^{*}\left(b_{t+1}, \varepsilon_{t}\right)$, the bond pricing function $q^{*}\left(b_{t+1}, \varepsilon_{t}\right)$ satisfies the arbitrage condition of foreign lenders (33).

Condition 1 requires that the sovereign government's default and saving/borrowing decisions be optimal given the interest rates on sovereign debt. Condition 2 requires that the private consumption allocations implied by these optimal borrowing and default choices be both feasible and consistent with a competitive equilibrium (recall that the resource constraint of the sovereign's optimization problem considers only private-sector allocations that are competitive equilibria). Condition 3 requires that the decision rule for government transfers shifts the appropriate amount of resources between the government and the private sector (i.e. an amount equivalent to net exports when the country has access to world credit markets, or the diverted repayment of working capital loans when a default occurs, or zero when the economy is in financial autarky beyond the date of default). Notice also that given conditions 2 and 3, the consumption plan satisfies the households' budget constraint. Finally, Condition 4 requires the equilibrium bond prices that determine country risk premia to be consistent with optimal lender behavior.

A solution to the above recursive equilibrium includes solutions for the private sector equilibrium allocations with and without credit market access. A solution for equilibrium interest rates on working capital as a function of $b_{t+1}$ and $\varepsilon_{t}$ follows from (34). Expressions for equilibrium wages, profits and the price of domestic inputs as functions of $r_{t}$ and $\varepsilon_{t}$ follow then from the firms' optimality conditions and the definitions of profits described earlier.

\section{Country Risk and Default Costs in Partial Equilibrium}

\subsection{Interest Rate Changes and Factor Allocations}

The effects of interest rate changes on the factor allocations of the private competitive equilibrium play a central role in our model because they are a key determinant of both output dynamics and the output cost of default. We illustrate these effects by means of a partialequilibrium numerical example in which the interest rates is exogenous. We use the parameter values set in the calibration exercise of Section 4 , and solve for private sector factor allocations and prices using conditions (13)-(20) with different values of $r$.

Figure 2 shows six charts with the allocations of $L, L^{f}, L^{m}, M, m^{d}$, and $m^{*}$ for values of $r$ ranging from 0 to 80 percent. Each chart includes results for the baseline calibration value of $\mu$ (0.69), which corresponds to an elasticity of substitution between foreign and domestic inputs of 3.23 , and for two lower elasticities (1.93, which is the threshold below which $m^{d}$ and $m^{*}$ switch from gross substitutes to gross complements, and the Cobb-Douglas case of unitary elasticity of substitution). ${ }^{16}$ To facilitate comparison across the different scenarios,

\footnotetext{
${ }^{16}$ Note that the threshold would be at the unitary elasticity of substitution if labor supply were inelastic.
} 
the results are plotted as ratios relative to the allocations when $r=0$.
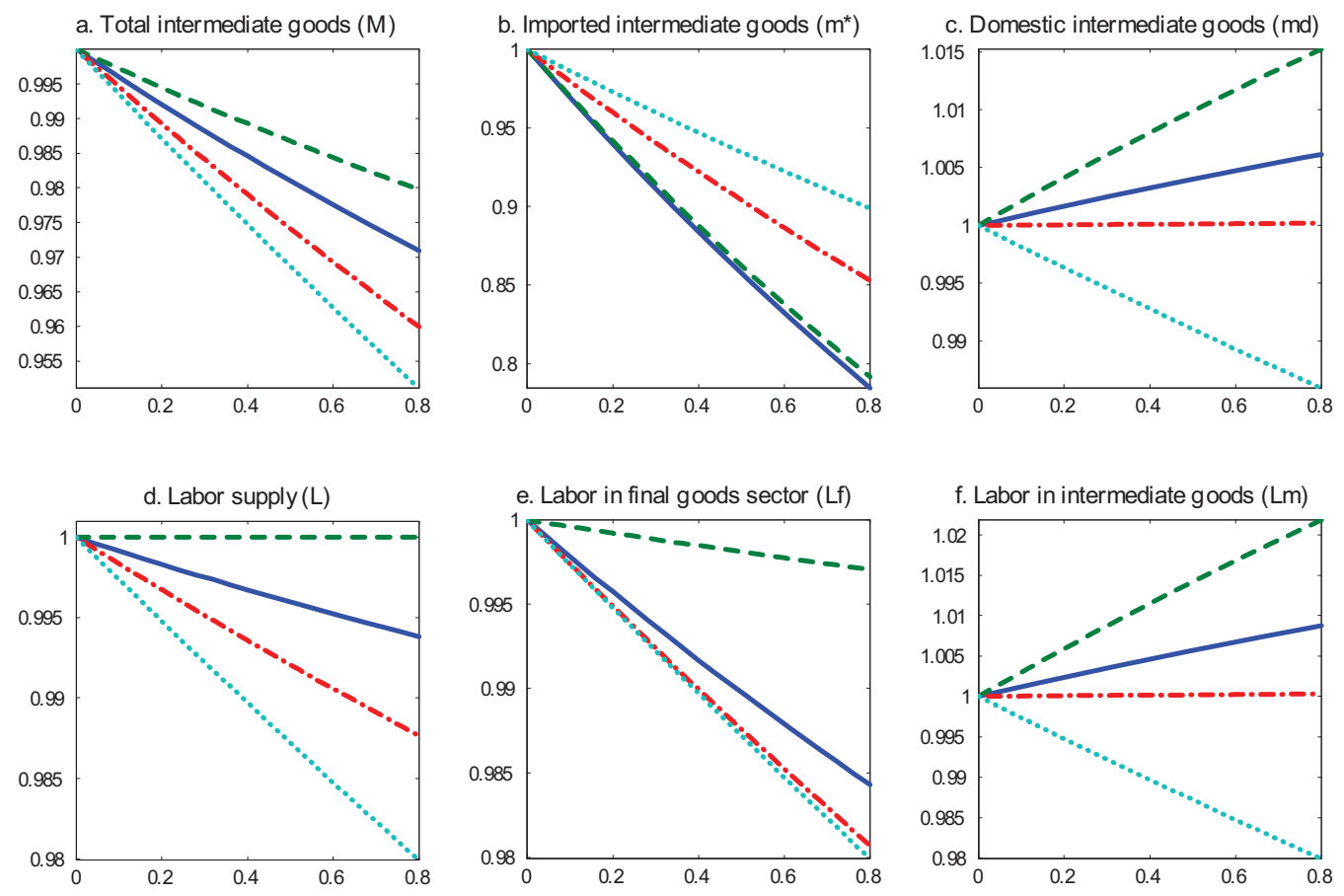

—Baseline(3.23) - - - Baseline w. inelastic labor(3.23) $\quad \cdots$ - Threshold elasticity(1.93) $\quad \ldots . .$. Cobb-Douglas(1)

Figure 2: Effects of interest rate shocks on intermediate goods and labor allocations at different Armington elasticities of substitution (ratios relative to allocations at zero interest rate)

The charts in Figure 2 illustrate three effects by which increases in the rate of interest affect equilibrium factor allocations. First, as chart $2 \mathrm{~b}$ shows, an increase in $r$ reduces the demand for $m^{*}$ because of the direct effect by which the hike in $r$ increases the marginal cost of imported inputs $p_{m}^{*}(1+\theta r)$, and this is the case for any $0<\mu<1$. Second, an increase in the interest rate has indirect effects that lower the demand for total intermediate goods $(M)$ and labor in the final goods sector $\left(L^{f}\right)$, because of the Cobb-Douglas structure of the production function of final goods (see charts $2 \mathrm{a}$ and $2 \mathrm{e}$ ). The direction of these effects is also the same for any $0<\mu<1$. Third, an increase in $r$ has effects on factor allocations in the intermediate goods sector, but the direction of these do depend on the value of $\mu$ (within the $(0,1)$ range). In particular, higher $r$ leads to an increase or a decline in $m^{d}$ and $L^{m}$ depending on whether the value of $\mu$ makes imported and domestic inputs gross substitutes or complements (see charts $2 \mathrm{c}$ and $2 \mathrm{f}$ ). If $\mu$ is high (low) enough for the two inputs to be gross substitutes (complements), both $m^{d}$ and $L^{m}$ increase (fall) as $p_{m}^{*}(1+\theta r)$ rises, so $m^{d}$ 
and $L^{m}$ rise (fall) as $m^{*}$ falls. As a result, the decline in $M$ and $L$ produced by an increase in the rate of interest is larger when domestic and foreign inputs are gross complements than when they are gross substitutes (as shown in charts $2 \mathrm{a}$ and $2 \mathrm{~d}$ ).

Figure 2 also shows results for the baseline value of $\mu$ but assuming that labor supply is inelastic. Comparing this scenario with the baseline case illustrates how the elasticity of labor supply affects the responses of factor allocations to interest rate changes. The effect on $\mathrm{m}^{*}$ is nearly unchanged when labor supply inelastic. $M$ falls less with inelastic labor, however, because $m^{d}$ rises more, and this is possible because with inelastic labor supply $L$ cannot fall in response to interest rate hikes, and this results in a larger increase in $L^{m}$ and a smaller decline in $L^{f}$. Thus, even with inelastic labor supply, increases in $r$ affect the efficiency of production by inducing a shift from foreign to domestic inputs, and by reallocating a given total endowment of labor supply from production of final goods to production of intermediate goods.

\subsection{Output costs of default}

Using the same numerical example, we can now examine how the output cost of default varies with $\varepsilon$, and how this relationship depends on $\mu$ and $\omega$. Figure 3 shows the output cost of default as a function of $\varepsilon$ for the baseline value of $\mu(0.69$, which implies an Armington elasticity of 3.23) and for a higher $\mu$ consistent with an Armington elasticity of 1.93. For each value of $\varepsilon$ in the horizontal axis, the output cost of default is computed as the percent fall in output that occurs when the government defaults (i.e. the value implied by the factor allocations that result from conditions (21)-(25)) relative to the level of output consistent with an interest rate of 1 percent (i.e. the value implied by conditions (13)-(20) with $r=0.01$ ).

Figure 3 illustrates two key properties of the model: First, the output cost of default is increasing and strictly convex in $\varepsilon$. This is the case because, with Cobb-Douglas production technologies and competitive markets, the negative effect of increases in marginal costs on factor demands is larger at higher TFP levels. ${ }^{17}$ Second, the cost of default is a steeper function of $\varepsilon$ at lower, but higher-than-unitary, Armington elasticities. ${ }^{18}$ This is an implication of the previous results showing that the negative effects of interest rate shocks on factor allocations are larger when domestic inputs are poorer substitutes of imported inputs.

\footnotetext{
${ }^{17}$ This is the case in turn because of the "strong" convexity of Cobb-Douglas marginal products. Consider for simplicity the case in which production $\varepsilon F(m)$ requires a single input $m$. In this case, "strong convexity" means that $F(m)$ satisfies $F^{\prime \prime \prime}(m)>\left(F^{\prime \prime}(m)\right)^{2} / F^{\prime}(m)$, which holds in the Cobb-Douglas case.

${ }^{18}$ Elasticities higher than unitary are necessary for this result because, as $\mu \rightarrow 0$ and the Armington elasticity approaches 1, output in the default scenario vanishes, and thus the cost of default converges to 100 percent and becomes independent of the level of TFP.
} 
Output Costs of Default as a Function of TFP Shock

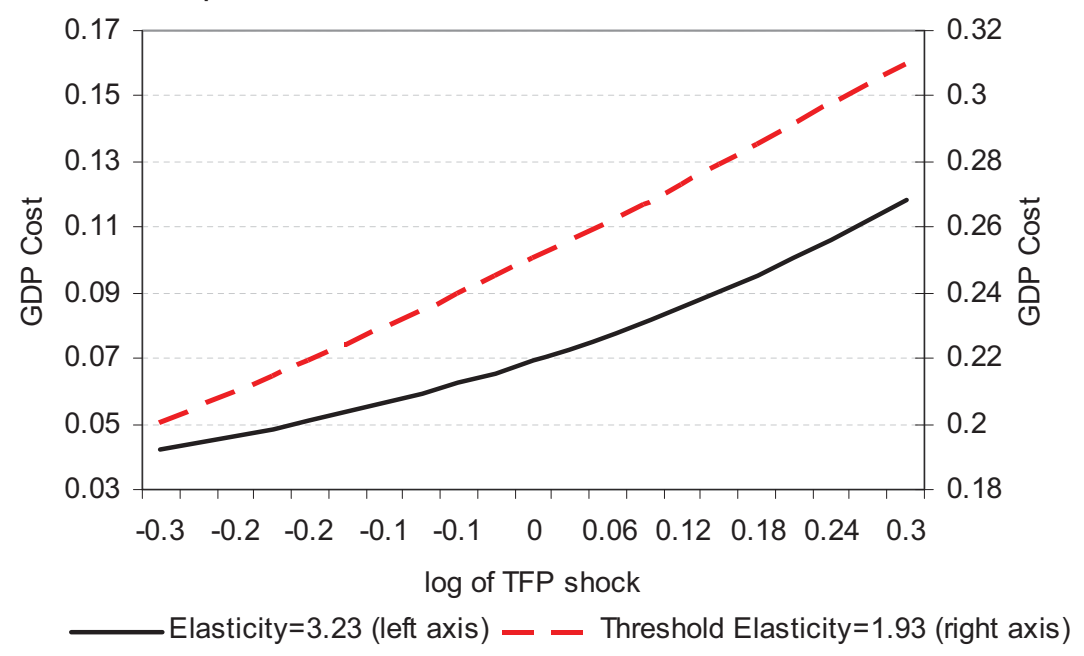

Figure 3: Output Costs of Default as a Function of TFP Shock

The fact that the output cost of default increases with $\varepsilon$ implies that default is more painful at higher TFP levels. This result plays a key role in enabling the model to support high debt levels at the observed default frequencies, and producing defaults in "bad" times, because it makes default more attractive at lower states of productivity. In this way, default works as a desirable implicit hedging mechanism given the incompleteness of asset markets.

Figure 4 illustrates further how the cost of default declines as the Armington elasticity rises. In this Figure, we show the output cost of default for a constant value of TFP $(\varepsilon=1)$ at different elasticities. Again, the cost of default becomes smaller at higher elasticities because the inputs are closer substitutes, and hence the efficiency loss when firms shift to use only domestic inputs is smaller. Quantitatively, the Figure shows that already at Armington elasticities in excess of 4 , the mechanism driving efficiency losses in our model becomes very weak and is effectively the same as if the inputs were perfect substitutes.

A similar analysis of the output costs of default as the one illustrated in Figures 3 and 4 but for different values of $\omega$ (instead of $\mu$ ) shows that a higher labor supply elasticity (i.e. lower $\omega$ ) increases the cost of default, converging to about 11.5 percent for infinitely elastic labor supply. The output cost of default is increasing in TFP for any value of $\omega$, but, in contrast with what we found for $\mu$, the slope of the relationship does not change as $\omega$ changes. $^{19}$

\footnotetext{
${ }^{19}$ We also found that adjusting the productivity parameter in production of intermediate goods $(A)$ has qualitatively similar effects as changing $\omega$.
} 


\section{Output costs of default for a neutral TFP shock at different elasticities of substitution}

Elasticity of substitution between foreign and domestic

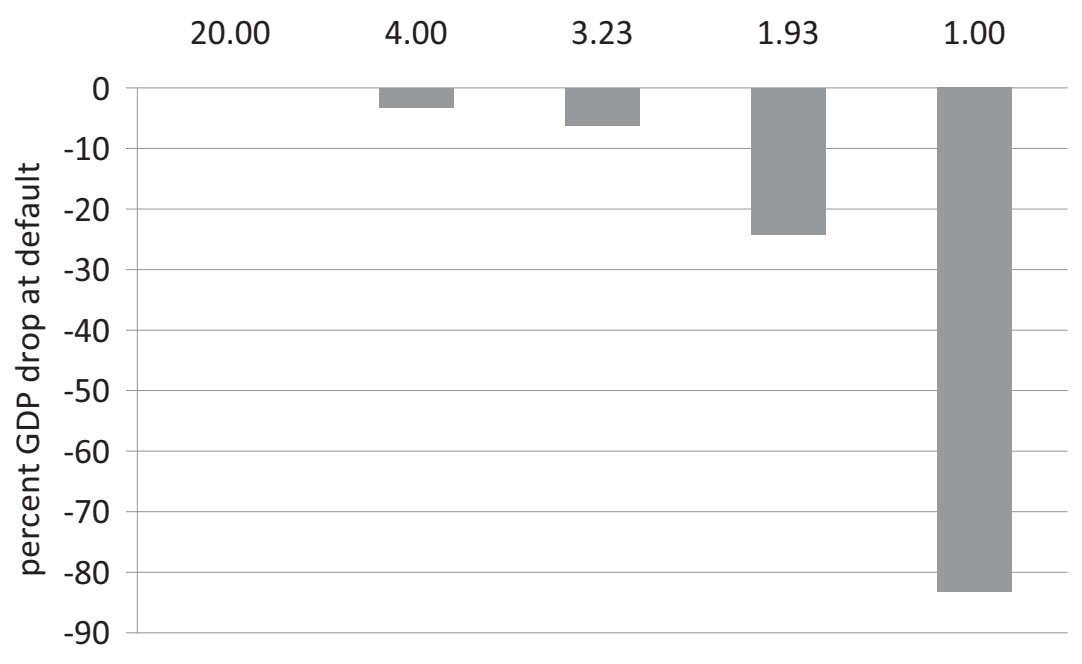

Figure 4: Output Costs of Default at a Neutral TFP Shock

The labor market equilibrium illustrated in Figure 5 provides the intuition behind the result that higher labor supply elasticity produces larger output costs of default.

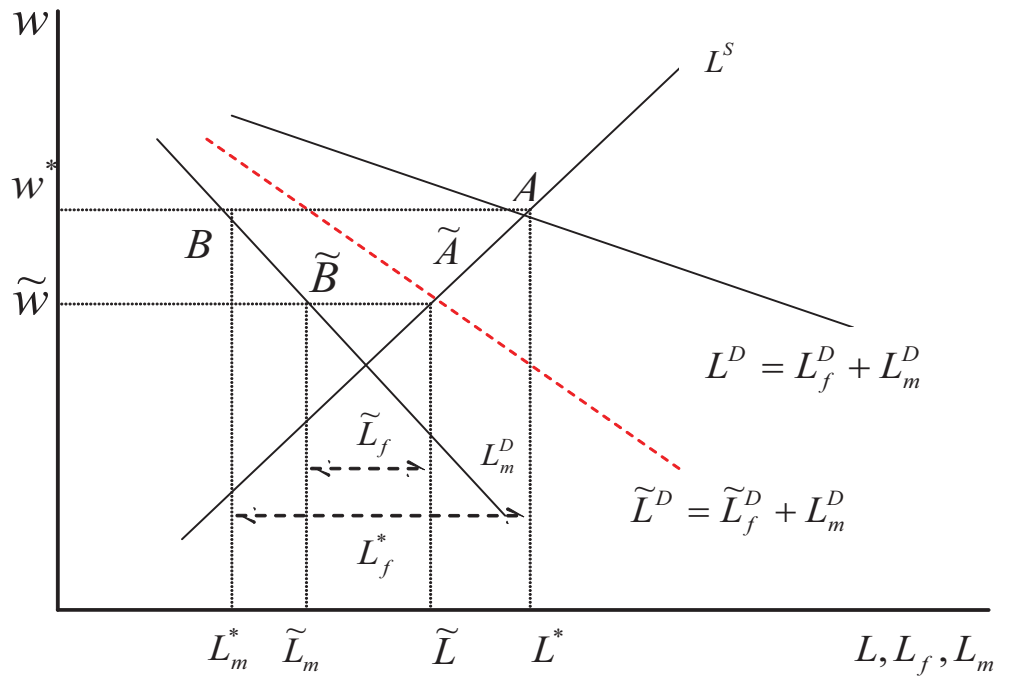

Figure 5: Interest Rate Shocks and the Labor Market Equilibrium 
For simplicity, we plot labor demands and supply as linear functions. The labor demand functions are given by the marginal products in the left-hand-side of (10) and (12), and the labor supply is given by the marginal disutility of labor in the left-hand-side of (3). Since labor is homogenous across sectors, total labor demand is just the sum of the sectoral labor demands. The initial labor market equilibrium is at point $\mathrm{A}$ with wage $w^{*}$, total labor $L^{*}$ and sectoral allocations $L_{m}^{*}$ and $L_{f}^{*}$.

Consider now a positive interest rate shock. This leads to a reduction in labor demand in final goods from $L_{f}^{D}$ to $\tilde{L}_{f}^{D}$. This occurs because, as explained earlier, higher $r$ causes a reduction in $M$ and the marginal product of $L_{f}$ is a negative function of $M$ (since the production function of final goods is Cobb-Douglas). As a result, total labor demand shifts from $L^{D}$ to $\widetilde{L}^{D} .^{20}$ The new labor market equilibrium is at point $\widetilde{A}$. The wage rate, the total labor allocation, and the labor allocated to final goods are lower than before, while labor allocated to production of domestic inputs rises (assuming that foreign and domestic inputs are gross substitutes).

Consider now how the results shown in Figure 5 would change if labor is infinitely elastic. In this case, $L^{s}$ is an horizontal line at the level of $w^{*}$ and the interest rate hike leaves $w$ unchanged instead of reducing it. As a result, $L$ falls more, $L_{m}$ is unchanged instead of rising, and $L_{f}$ falls less. ${ }^{21}$ Hence, the adverse effect on output is stronger. Going to the other extreme, if labor is inelastic, $L^{s}$ is a vertical line at the level of $L^{*}$. Now $L$ cannot change, but $w$ falls more than in the scenario plotted in Figure $5, L_{m}$ rises more, and $L_{f}$ falls more. Hence, the decline in output is smaller.

\section{Quantitative analysis}

\subsection{Calibration}

We study the quantitative implications of the model by conducting numerical simulations setting the model to a quarterly frequency and using a benchmark calibration based mostly on data for Argentina, as is typically done in the related literature on quantitative studies of sovereign default. Table 2 shows the parameter values of this benchmark calibration.

The risk aversion parameter $\sigma$ is set to 2 and the quarterly world risk-free interest rate $r^{*}$ is set to 1 percent, which are standard values in quantitative business cycle and sovereign default studies. The curvature of labor disutility in the utility function is set to $\omega=1.455$, which implies a Frisch wage elasticity of labor supply of $1 /(\omega-1)=2.2$. This is the value

\footnotetext{
${ }^{20}$ In Figure 5, we hold constant $p_{m}$ for simplicity. At equilibrium, the relative price of domestic inputs changes, and this alters the value of the marginal product of $L d$, and hence labor demand by the $m$ sector. The results of the numerical example do take this into account and still are roughly in line with the intuition derived from Figure 5 .

${ }^{21}$ The last effect hinges on the fact that the gap between $L_{m}^{D}$ and $L^{D}$ widens as the wage falls. This is a property of factor demands with Cobb-Douglas production.
} 
typically used in RBC models of the small open economy (e.g. Mendoza (1991) and Neumeyer and Perri (2005)), and is based on estimates for the U.S. quoted by Greenwood, Hercowitz and Huffman (1988). The probability of re-entry after default is 0.125 , which implies that the country stays in exclusion for 2 years after default on average. This estimate is in the range of the estimates reported by Gelos et al. (2003) and Richmond and Dias (2007). ${ }^{22}$

Table 2: Benchmark Model Calibration

\begin{tabular}{llllll}
\hline \hline Calibrated Parameters & & Value & Target statistics & \\
\hline CRRA risk aversion & $\sigma$ & 2 & Standard RBC value & \\
Risk-free interest rate & $r^{*}$ & $1 \%$ & Standard RBC value & \\
Capital share in gross output of final goods & $\alpha_{k}$ & 0.17 & Standard capital share in GDP (0.3) \\
Int. goods share in gross output of final goods & $\alpha_{m}$ & 0.43 & Share of int. goods in gross output \\
Labor share in gross output of final goods & $\alpha_{L}$ & 0.40 & Standard labor share in GDP $(0.7)$ \\
Labor share in GDP of int. goods & $\gamma$ & 0.7 & Standard labor share in GDP $(0.7)$ \\
Curvature parameter of labor supply & $\omega$ & 1.455 & Frisch wage elasticity $(2.2)$ \\
Re-entry probability & $\eta$ & 0.125 & Length of exclusion $(2$ years $)$ \\
\hline Parameters set with SMM & & Value & Targets from data & \\
\hline Productivity persistence & $\rho_{\varepsilon}$ & 0.90 & GDP autocorrelation & 0.79 \\
Productivity innovations std. dev. & $\sigma_{\epsilon}$ & $2.14 \%$ & GDP std. deviation & $4.70 \%$ \\
Intermediate goods TFP & $A$ & 0.20 & Output drop in default & $13 \%$ \\
Armington weight of domestic inputs & $\lambda$ & 0.61 & Nominal imported- & $18 \%$ \\
& & & domestic inputs ratio & \\
Armington curvature parameter & $\mu$ & 0.69 & Real imported- & $16 \%$ \\
& & & domestic inputs ratio & \\
Subjective discount factor & $\beta$ & 0.87 & Default frequency & $0.69 \%$ \\
Working capital coefficient & $\theta$ & 0.10 & Trade balance volatility & $2.88 \%$ \\
\hline \hline
\end{tabular}

The share of intermediate goods in gross output $\alpha_{M}$ is set to 0.43 , which corresponds to the average ratio of intermediate goods purchases to gross production calculated using annual data for Argentina for the period 1993-2005 from the United Nation's UNData. ${ }^{23}$ Given $\alpha_{M}$, we set $\alpha_{k}=0.17$ so that the capital income share in value added of the $f$ sector $\left(\alpha_{k} /\left(1-\alpha_{M}\right)\right)$ matches the standard 30 percent $(0.17 /(1-0.43)=0.3)$. These factor shares imply a labor share in gross output of final goods of $\alpha_{L}=1-\alpha_{M}-\alpha_{k}=0.40$, which yields a labor share

\footnotetext{
${ }^{22}$ The two studies use different definitions of re-entry into world credit markets. Gelos et al. use actual external bond issuance of public debt. Dias and Richmond define rentry whenever either the private or public sectors can borrow again, and they also distinguish partial reaccess from full reaccess (with the latter defined as positive net debt flows larger than 1.5 percent of GDP). However, the two studies do not differ much in terms of the estimates of the duration of exclusion. Gelos et al. estimate and avearge of 5.4 years in the $1980 \mathrm{~s}$ and nearly 1 year in the 1990s. Dias and Richmond estimate 1.8 year for partial market reaccess and 4.8 year for full market reaccess.

${ }^{23}$ Mendoza (2010) reports a very similar share for Mexico, and Gopinath, Itskhoki, and Rigobon (2010) show shares in the 40-45 percent range for several countries.
} 
in value added $\alpha_{L} /\left(1-\alpha_{M}\right)=0.7$ that matches the standard 70 percent. The labor share in intermediate goods production $\gamma$ is also set to 0.7 , since this is also the share of labor in value added in the $m$ sector.

Productivity shocks in final goods production follow an $\mathrm{AR}(1)$ process:

$$
\log \varepsilon_{t}=\rho_{\varepsilon} \log \varepsilon_{t-1}+\epsilon_{t}
$$

with $\epsilon_{t} \stackrel{\text { iid }}{\sim} N\left(0, \sigma_{\epsilon}^{2}\right)$. We use a Markov approximation to this process with 25 realizations constructed using the method proposed by Tauchen (1986). Data limitations prevent us from estimating (35) directly using actual TFP data, so we set $\sigma_{\epsilon}^{2}$ and $\rho_{\varepsilon}$ (together with other parameters discussed below) using the simulated method of moments (SMM) set to target a set of moment conditions from the data. The target moment conditions for $\sigma_{\epsilon}^{2}$ and $\rho_{\varepsilon}$ are Argentina's standard deviation and first-order autocorrelation of quarterly H-P detrended GDP. We use seasonally-adjusted quarterly real GDP from the Ministry of Finance (MECON) for the period 1980Q1 to 2005Q4. The standard deviation and autocorrelation of the cyclical component of GDP are 4.7 percent and 0.79 respectively. The process of productivity shocks derived using SMM features $\rho_{\varepsilon}=0.90$ and $\sigma_{\epsilon}=2.14$ percent.

The additional parameters calibrated using SMM are $\mu, \lambda, A, \beta$, and $\theta$. These parameters are targeted to match the average nominal and real expenditure ratios of imported to domestic inputs, the fraction of output loss at default, the frequency of default, and the volatility of the trade balance-GDP ratio. ${ }^{24}$ Serious limitations of the national accounts data for Argentina prevent us from computing target expenditure ratios of imported v. domestic inputs, so we compute them instead using Mexican data for the period 1988-2004. The average ratios of imported to domestic inputs at current and constant prices are 18 and 15.7 percent respectively. We assume that Argentina has similar ratios. ${ }^{25}$ The default frequency is 0.69 percent because Argentina has defaulted five times on its external debt since 1824 (the average default frequency is 2.78 percent annually or 0.69 percent quarterly). The output loss at default is set to 13 percent. This corresponds to the deviation from the H-P trend in Argentina's quarterly GDP as of the first quarter of 2002. ${ }^{26}$ The standard deviation of Argentina's quarterly trade balance-to-GDP ratio is 2.88 percent.

The SMM estimate of $\mu$ is 0.69 and the estimate of $\lambda$ is 0.61 , so the Armington elasticity

\footnotetext{
${ }^{24} A$ can be used to target the output drop at default because, as mentioned in Section 2 , changes in $A$ have similar effects as changes in $\omega$. In particular, lower values of $A$ yield larger output drops at default without altering the slope of the relationship between TFP and these output drops.

${ }^{25}$ Several industrial countries have input expenditure ratios similar to Mexico's, but the ratios vary widely across countries. Goldberg and Campa (2008) report ratios of imported inputs to total intermediate goods for 17 industrial countries that vary from 14 to 49 percent, with a median of 23 percent. This implies ratios of imported to domestic inputs in the 16 to 94 percent range, with a median of 30 percent.

${ }^{26}$ Argentina declared default in the last week of December in 2001, but it is reasonable to assume that, in quarterly data, the brunt of the real effects of the debt crisis were felt in the first quarter of 2002. Arellano (2008) also follows this convention to date the default as of the first quarter of 2002. She estimated the output cost at 14 percent, measured as a deviation from a linear trend.
} 
of substitution between $m^{*}$ and $m^{d}$ is 3.23 and there is a small bias in favor of domestic inputs. Interestingly, these values are very similar to econometric estimates we obtained using the 17 observations available from the Mexican data for 1988-2004. We estimated $\mu$ and $\lambda$ by applying non-linear least squares on the condition equating the marginal rate of technical substitution between $m^{*}$ and $m^{d}$ with the corresponding relative price (derived using conditions (8) and (9)), and we obtained estimates of $\mu=0.66$ and $\lambda=0.62$, both statistically significant (with standard errors of 0.11 and 0.12 respectively).

The calibrated Armington elasticity of substitution of 3.23 is in the range of existing empirical estimates, but these estimates vary widely. McDaniel and Balistreri (2002) review the literature and quote estimates ranging from 0.14 to 6.9. They explain that elasticities tend to be higher when estimated with disaggregated data, in cross-sectional instead of time-series samples, or when using long-run instead of short-run tests.

The subjective discount factor is 0.87 , which is in the range of the values used in existing studies on sovereign default. ${ }^{27}$ The estimate for $A$ is 0.2 . Finally, the estimate for $\theta$ implies that firms pay only $1 / 10$ of the cost of imported inputs in advance.

In the subsections that follow we examine different aspects of the model's numerical solution based on this benchmark calibration. In order to obtain solutions that apply to the model's stochastic stationary state, we feed the TFP process to the model and conduct 2000 simulations, each with 500 periods and truncating the first 100 observations.

\subsection{Cyclical Co-movements in the Benchmark Simulation}

This subsection examines the ability of the benchmark model to account for the observed statistical moments of business cycles and sovereign debt. Table 3 compares the moments produced by the model with moments from Argentine data. The bond spreads data are quarterly EMBI+ spreads on Argentine foreign currency denominated bonds from 1994Q2 to 2001Q4, taken from J.P. Morgan's EMBI+ dataset.

Table 3 shows that the model yields a negative correlation between spreads and GDP, and this is because sovereign bonds have higher default risk in bad states. As we noted in the Introduction, both quantitative models of sovereign debt and of business cycles in emerging economies also produce countercyclical spreads, but in the former output is an exogenous stochastic endowment and in the latter country risk is exogenous. In contrast, our model produces countercyclical country risk in a setting in which both output and country risk are endogenous, and influence each other because of the "credit channel" linking country risk, the cost of working capital, and the private sector equilibrium.

\footnotetext{
${ }^{27}$ The values of $\beta$ in Aguiar and Gopinath (2006), Arellano (2008), and Yue (2010) range from 0.8 to 0.953.
} 
Table 3: Statistical Moments in Benchmark Model Simulation and in the Data

\begin{tabular}{lll}
\hline Statistics & Data & Model \\
\hline Corr. between Bond Spreads and GDP & -0.62 & -0.19 \\
Corr. between Bond Spreads and Trade Balance & 0.68 & 0.18 \\
Corr. between Trade Balance and GDP & -0.58 & -0.24 \\
Consumption Std. Dev./Output Std. Dev. & 1.44 & 1.31 \\
Average Debt/GDP & $35 \%$ & $23.11 \%$ \\
Bond Spreads Std. Dev. & $0.78 \%$ & $0.71 \%$ \\
Average Bond Spreads & $1.86 \%$ & $0.58 \%$ \\
Corr. between total labor and Spreads & - & -0.21 \\
Corr. between total labor and GDP & - & 0.72 \\
Corr. between $M$ and Spreads ${ }^{1}$ & -0.39 & -0.17 \\
Corr. between $M$ and GDP $^{1}$ & 0.90 & 0.97 \\
Corr. between default and GDP $^{1}$ & $-0.11^{2}$ & -0.12 \\
Fraction of defaults with GDP below trend $^{1}$ & $36.49 \%^{2}$ & $89 \%$ \\
Fraction of defaults with GDP 2 std dev. below trend $^{1}$ & $23.6 \%^{2}$ & $30 \%$ \\
\hline \hline
\end{tabular}

${ }^{1}$ Statistical moment computed at annual frequency

${ }^{2}$ Cross-country historical estimate for 1820-2004 from Tomz and Wright (2007)

The model is also consistent with two key stylized facts of emerging markets business cycles: countercyclical net exports and consumption variability that exceeds output variability. The first result follows from the fact that, when the country is in a bad TFP state, it faces higher interest rates and tends to borrow less. The country's trade balance thus increases because of the lower borrowing, leading to a negative correlation between net exports and output. The second result occurs because the ability to use external debt to smooth consumption is negatively affected by the higher interest rates induced by increased default probabilities. The sovereign borrows less when the economy faces an adverse TFP shock, and thus households adjust consumption by more than in the absence of default risk. On the other hand, because agents are impatient, the benevolent government borrows more to increase private consumption when the TFP shock is good. Hence, the variability of consumption rises. As with the countercyclical spreads, existing models of sovereign debt and emerging markets business cycles can produce similar results, but not without assuming that either country risk or output fluctuations are exogenous.

The model produces a debt-to-GDP ratio of 23 percent on average. This high debt ratio is mainly the result of the large output drop that occurs when the country defaults, and the increasing output cost of default as a function of TFP. Although a 23 percent debt ratio is still below Argentina's 35 percent average debt-output ratio (based on data from the World Bank's WFD dataset for the 1980-2004 period), it is much larger than the debt ratios typically obtained in quantitative models of sovereign default with exogenous output 
costs already targeted to improve the models' quantitative performance. For instance, Yue's (2010) model with renegotiation and an exogenous two-percent proportional output cost of default yields an average debt ratio of 9.7 percent. Arellano (2008) obtains a mean debt ratio of 6 percent of GDP with an asymmetric output cost of default that lowers income when the economy defaults to the maximum of actual output or 97 percent of average output. ${ }^{28}$

The model also matches closely the volatility of the Argentine bond spreads observed in the data. Yet the average bond spread is lower than in the data. Because we assume a zero recovery rate on defaulted debt and risk-neutral creditors, bond spreads are linked one-to-one with default probabilities (see eq. (33)). Since the quarterly default frequency is 0.7 percent (as in the data), the model can only generate an average bond spread of a similar magnitude, which is about $1 / 3$ of the average spreads observed in the data.

The model predicts correlations of intermediate goods with sovereign spreads and GDP in line with those observed in the data. Using the annual UN data on Argentina's intermediate goods from 1994 to 2005, we find that the correlation between GDP and intermediate goods from is 0.90 (compared with 0.97 in the model). The correlation between spreads and intermediate goods before the 2001 default is -0.39 (compared with -0.17 in the model). ${ }^{29}$ In the model, this negative correlation is due to the credit transmission mechanism that operates via the working capital requirement (as explained in subsection 2.5). This mechanism is also behind the negative correlation between labor and spreads. In turn, intermediate goods and labor are positively correlated with GDP because of the standard real-business-cycle effects of TFP shocks and because of the reinforcing effect of the countercyclical spreads.

We also report in Table 3 the correlation between defaults and GDP and the fractions of default events that occur when GDP is below trend and two-standard-deviations or more below trend. The data estimates of these moments are Tomz and Wright's (2007) crosscountry historical estimates based on data for the period 1820-2004. Because these are moments based on annual data, we show in the table the comparable annual-equivalent moments from the model. The correlation between defaults and GDP in the model is -0.12 , very close to the actual correlation. The model can produce defaults that occur in good times (defined as GDP above trend) at the annual frequency, but this happens only with 11 percent of defaults. Hence, 89 percent of defaults occur in "bad times," which is significantly more than in the data. On the other hand, the model is much closer to the data in the fraction of defaults that occur with deep recessions (defined as GDP two standard deviations or more below trend). This occurs with 30 percent of defaults in the model v. 24 percent of defaults in the data.

\footnotetext{
${ }^{28}$ As mentioned earlier, Aguiar and Gopinath (2006) obtained a higher mean debt ratio (27 percent of GDP) assuming a cost of 2 percent of output, but with a default frequency of only 0.02 percent.

${ }^{29}$ We exclude financial autarky periods in computing this correlation because in the model the spreads go to infinity when the economy defaults, and hence the correlation between $M$ and spreads is undefined.
} 


\subsection{Macroeconomic Dynamics around Default Events}

We study the model's ability to match V-shaped output dynamics around default episodes by applying event study techniques to the simulated time series data. Figure 6 plots the model's average path of output around default events together with the data for Argentina's HP detrended GDP around the recent default (1999Q1 to 2004Q3). The event window covers 12 quarters before and 10 quarters after debt defaults, with the default events normalized to date 0 . We plot the average for output in the model at each date $t=-12, \ldots, 10$ around default events in the 2000 simulations. Hence, the simulated GDP line represents the average behavior of output around defaults in the model's stochastic stationary state. Since Argentina's data is for a single default event, instead of a long-run average, we add dashed lines with one-standard-error bands around the model simulation average.

The model's mean output dynamics do very well at matching the magnitudes of the recession and recovery observed in the data, with output falling sharply when the country defaults to about 13 percent below the H-P trend on average. In addition, Argentina's output dynamics before and after the debt crisis are mostly within the one-standard-error bands of the model simulations.

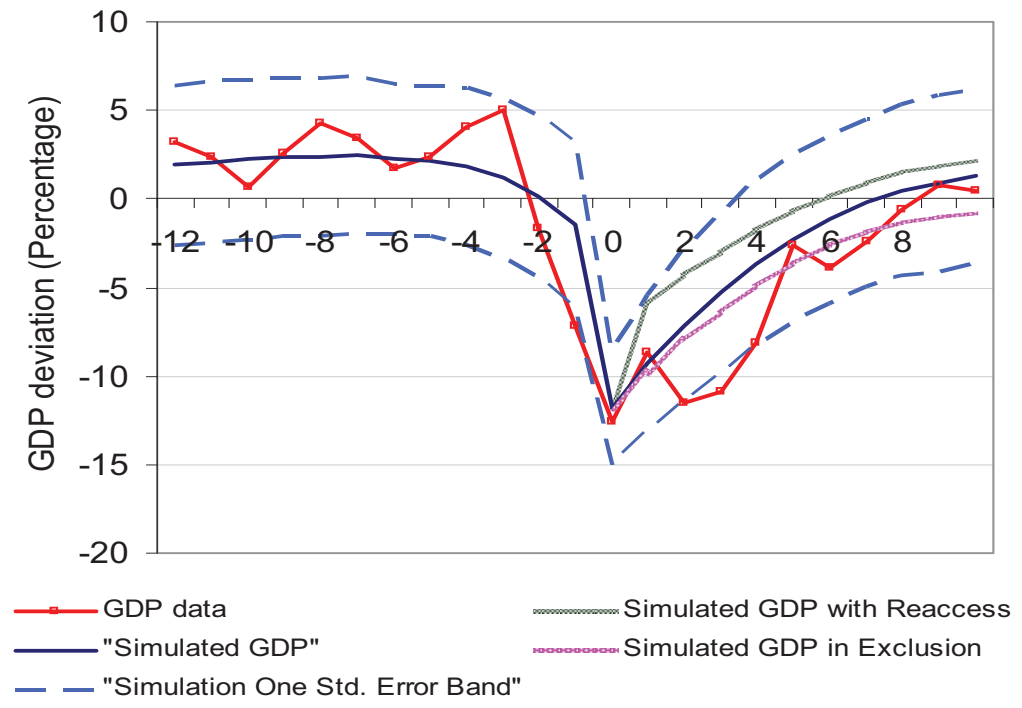

Figure 6: Output around Default Events

Defaults in the model are triggered by adverse TFP shocks, but these shocks are not unusually large. The standard deviation of the calibrated TFP process $\left(\sigma_{\varepsilon}\right)$ is 4.91 percent, which is about the same as the 5 percent average decline in TFP in default events (i.e. at $t=0$ in Figure 6). This suggests that the model's financial transmission mechanism amplifies significantly the real effects of TFP shocks when these shocks trigger default. 
The magnitude of the amplification effect can be quantified by computing the average output drop that the model produces in response to a 5 percent TFP shock when there is no default, and comparing it with the 13 percent mean output drop that the same shock produces when default occurs. Without default, a 5 percent TFP shock produces a mean output drop of about 7.2 percent. Thus, the amplification coefficient due to default is $13 / 7.2=1.8$. Default amplifies the output effect of TFP shocks by 80 percent.

The V-shaped recovery of output after default is driven by two effects. First, since $\varepsilon$ is mean-reverting, TFP is likely to improve after default (on average, $\varepsilon$ rises by 1 percent at $t=1)$. Therefore, even though the country remains in financial autarky on average from dates 1 to 10, the economy recovers because TFP improves. The second effect is the surge in output that occurs when the country re-enters credit markets (as final goods producers switch back to a more efficient mix of imported and domestic inputs).

The two effects that induce the post-default recovery are illustrated in Figure 6 by the lines that show the simulated paths of GDP with continued exclusion for 10 quarters after default and with immediate re-entry one period after default. In the first scenario, the recovery reflects only the effect of the mean reversion of $\varepsilon$. GDP in this case remains below that in the simulation average because the latter is also affected by the probability of credit-market re-entry. In contrast, the second scenario with immediate re-entry to international credit markets shows a big rebound in GDP at $t=1$, because of the efficiency gain obtained as final goods producers regain access to imported inputs. The simulation average lies below this immediate re-entry line because re-entry to credit markets is stochastic with 12.5 percent probability. Since re-entry has a relatively low probability, the model simulation for average GDP weighs more the effect of TFP recovery than the effect of credit market re-entry.

The model's V-shaped output dynamics are qualitatively consistent with the data of emerging markets that experienced Sudden Stops. Calvo, Izquierdo and Talvi (2006) conducted a cross-country empirical analysis of the recovery of emerging economies from Sudden Stops, and found that most recoveries are not associated with improvements in credit market access. In our model as well, recovery occurs (on average) even though the economy continues to be excluded from world credit markets.

The output dynamics also suggest that the model can account for the seemingly dominant role of productivity shocks in output collapses during financial crises. In particular, this can be the result of the efficiency loss caused by the change in the mix of intermediate goods and the sectoral reallocation of labor when the economy defaults. To demonstrate this point, we use the model's simulated data to compute Solow residuals in the standard way: We assume an aggregate Cobb-Douglas production function for economy-wide GDP, $g d p_{t}=s_{t}\left(L_{t}\right)^{a} k^{1-a}$, and compute the Solow residual $s$ using the model's data for $L$ and $g d p$, setting $a$ to the model's average of the ratio of total wage payments to GDP, $w_{t} L_{t} / g d p_{t}$, which is about 0.7 . By construction, however, the "true" TFP shock driving the model is $\varepsilon_{t}$ in the production 
function of final goods.

Figure 7 compares the quarter-on-quarter average growth rates of the Solow residual, true TFP and GDP around default events in the baseline calibration. There is little difference between the Solow residual and true TFP except when the economy defaults. In default events, the Solow residual overestimates the true adverse TFP shock by a large margin (on average, $s$ falls by nearly twice as much as $\varepsilon$ when the economy defaults).

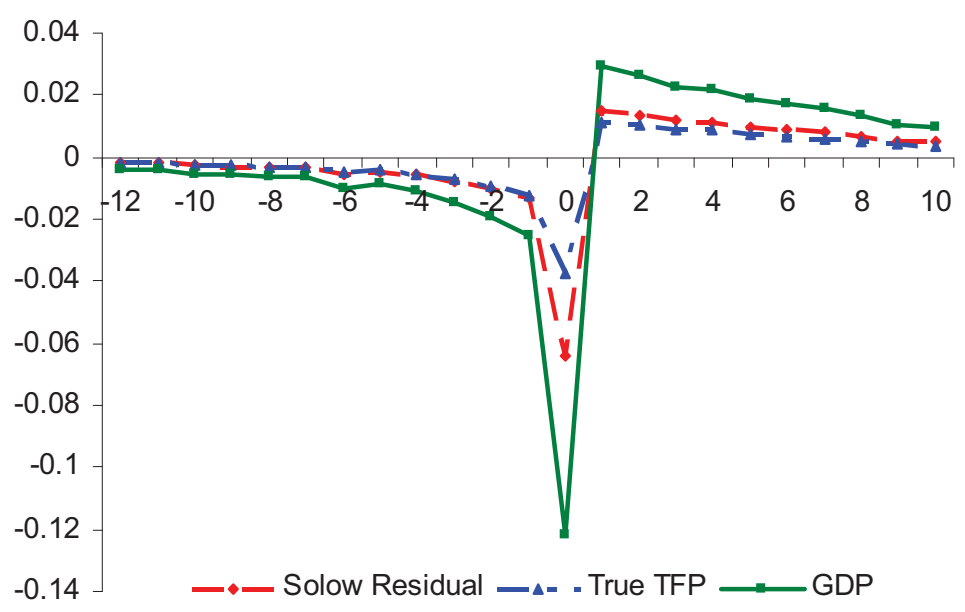

Figure 7: Growth Rates of GDP, True TFP and Solow Residual around Default

A standard decomposition of the contributions of changes in TFP and in factors of production to changes in GDP shows that the contribution of true TFP to the output collapse at default is about 31 percent. In contrast, the contribution of the Solow residual is nearly 53 percent, which would suggest misleadingly that the contribution of TFP shocks is 1.72 times larger than it actually is. The large difference between the two is due to the fact that the Solow residual treats the efficiency loss induced by the default as a reduction in aggregate TFP.

The model also matches nicely the actual dynamics of sovereign bond spreads before a debt crisis. The left panel of Figure 8 presents event windows showing output and bond spreads up to 12 quarters before default events in the stationary distribution of the model. This plot illustrates the negative correlation between output and bond spreads before a debt crisis. In particular, the spread increases as the country approaches a debt crisis. The average quarterly spread increases from 0.6 percent at $t=-12$ to almost 2.5 percent in the quarter before default. At the same time, HP detrended output starts to decline three quarters before default, and suffers a sharp drop when default occurs. These features match relatively well the Argentine experience. The right panel of Figure 8 shows the HP detrended real GDP 
and EMBI+ sovereign bond spreads for Argentina from 1999Q1 to 2001Q4. The data show a relatively stable sovereign spread before 2000 and a sharp increase in 2001, and Argentina also experienced a relatively steady output performance and then a deep recession starting in 2001. Notice, however, that spreads in the model are generally lower in levels than in the data (as explained earlier), and output in the data started to fall sharply a quarter earlier than the model predicts.
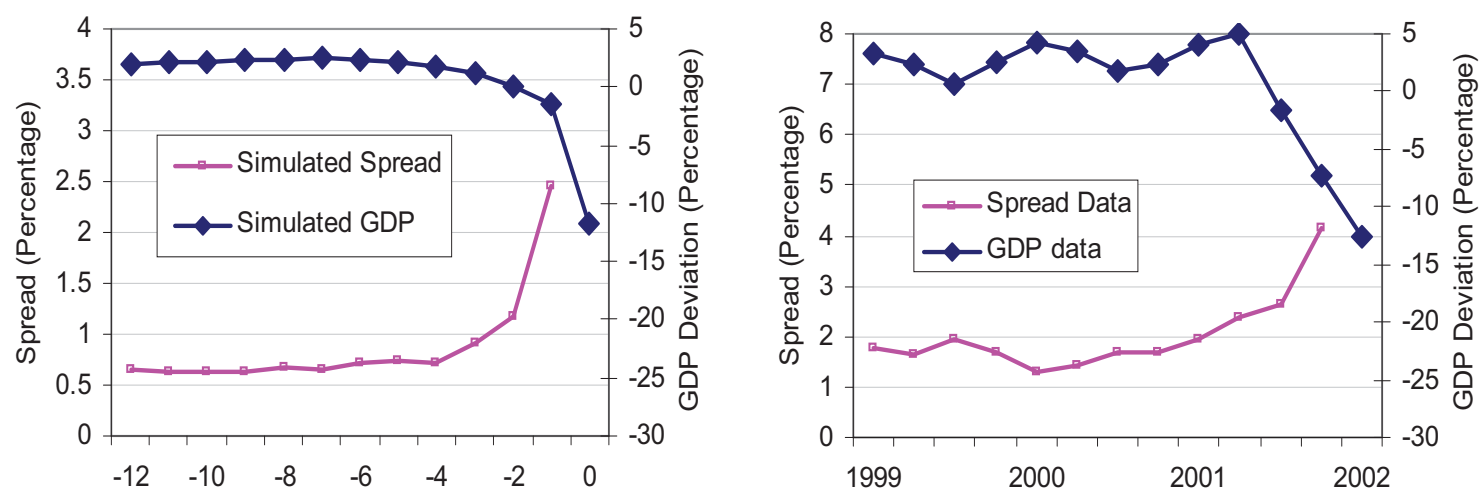

Figure 8: Dynamics of Output and Sovereign Spreads before a Debt Crisis

Figure 9 shows default event windows for the average of the model simulations of consumption, the current account, foreign bond holdings, labor, intermediate goods, and sectoral labor allocations (along with the corresponding one-standard-error bands).
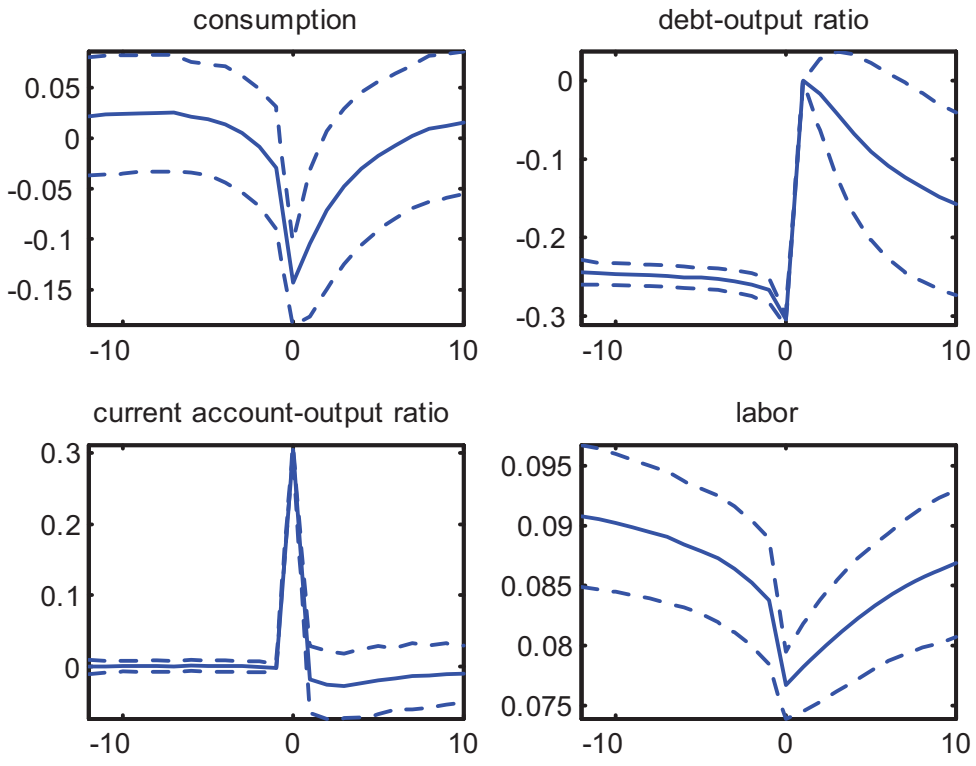

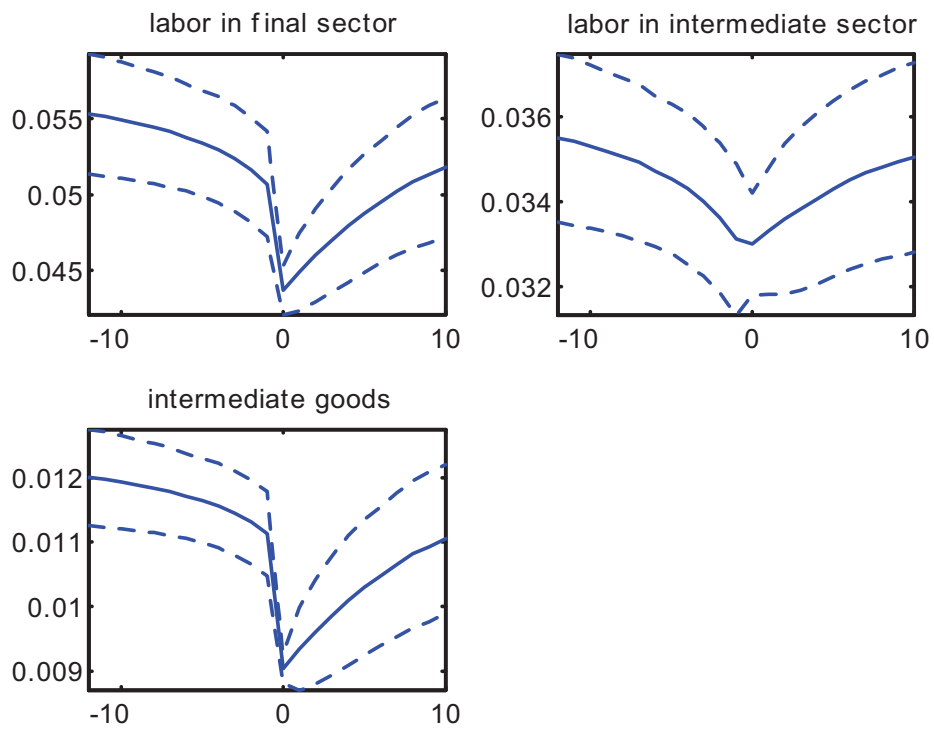

Figure 9: Macro Dynamics around Default Events

Consumption drops sharply when the government defaults and in the period that follows, and then it recovers following the $\mathrm{V}$-shaped dynamics of GDP. The debt-output ratio is over 23 percent on average before default, and it increases to about 32 percent in the period just before default. The model also generates a sharp reversal in the current account. The country runs a small current account deficit on average, but default, and the loss of credit market access that it entails, produce a large jump of about 30 percentage points of GDP in the current account. Labor and intermediate goods also fall sharply when the economy defaults. Moreover, since default triggers a shift from imported to domestic inputs in final goods production, labor is reallocated from the $f$ sector to the $m$ sector, and hence labor in the latter falls by less than in the former.

The sharp declines in GDP, consumption, labor and intermediate goods, together with the large reversal in the current account, indicate that the model yields predictions consistent with the Sudden Stops observed in emerging economies. In most of the Sudden Stops literature, however, the current account reversal is modeled as an exogenous shock, whereas in this model both the current account reversal and the economic collapse are endogenous. ${ }^{30}$

\footnotetext{
${ }^{30}$ Mendoza (2010) proposed an alternative model of endogenous Sudden Stops based on collateral constraints and Irving Fisher's debt-deflation mechanism instead of sovereign default risk.
} 


\section{$5 \quad$ Sensitivity Analysis}

In this Section we conduct a sensitivity analysis to study how the model's quantitative predictions change when we vary the working capital requirement $\theta$, the parameters of the Armington aggregator $\mu$ and $\lambda$, and the labor supply curvature parameter $\omega$. In reviewing these results, it is important to keep in mind that $\theta, \mu$ and $\lambda$ were calibrated using SMM to target statistics from actual data. Hence, the sensitivity analysis helps us explain how the model's results depend on these parameters, but the values of these parameters that best fit the model according to the SMM results are the benchmark values.

\subsection{Working Capital}

Column (I) of Table 4 shows the results of simulating the model without working capital. In this case, there is no endogenous output cost of default that rises with TFP. Output is low simply because TFP is low when default occurs, and there is also no financial amplification effect. To keep the results comparable with those reported in quantitative studies of sovereign debt that use exogenous proportional output costs of default (e.g. Aguiar and Gopinath (2006), Yue (2010)), we introduce here a similar exogenous proportional cost. The cost is set so that TFP falls by as much as needed to produce an output drop of 13 percent, which implies an output drop of the same magnitude as the endogenous drop in our baseline calibration. ${ }^{31}$ The other parameters are kept unchanged.

The model without working capital performs much worse than the benchmark in terms of its ability to match the important features of the data that the benchmark model approximated well (Column (II) of Table 4 reproduces the results of the benchmark model). The frequency of defaults falls from 0.6 percent to 0.12 percent. The mean debt ratio collapses to almost zero, and the average and standard deviation of country spreads fall by 46 and 55 basis points respectively. In addition, the GDP correlation of sovereign spreads increases to -0.04, and the correlation between spreads and net exports falls sharply from 0.18 to -0.21 . These results follow from two important differences in the model without working capital relative to the benchmark: First, the cost of default becomes independent of TFP, and second, bond spreads no longer have a direct impact on production. As a result, debt is not as good a hedging mechanism as in the benchmark model, making default more painful ex ante in the model without working capital, and thus reducing the average debt ratio.

\footnotetext{
${ }^{31}$ Even without working capital, output is endogenous in the model, and hence $M$ and $L$ respond to TFP changes.
} 
Table 4: Changes in the Working Capital Constraint

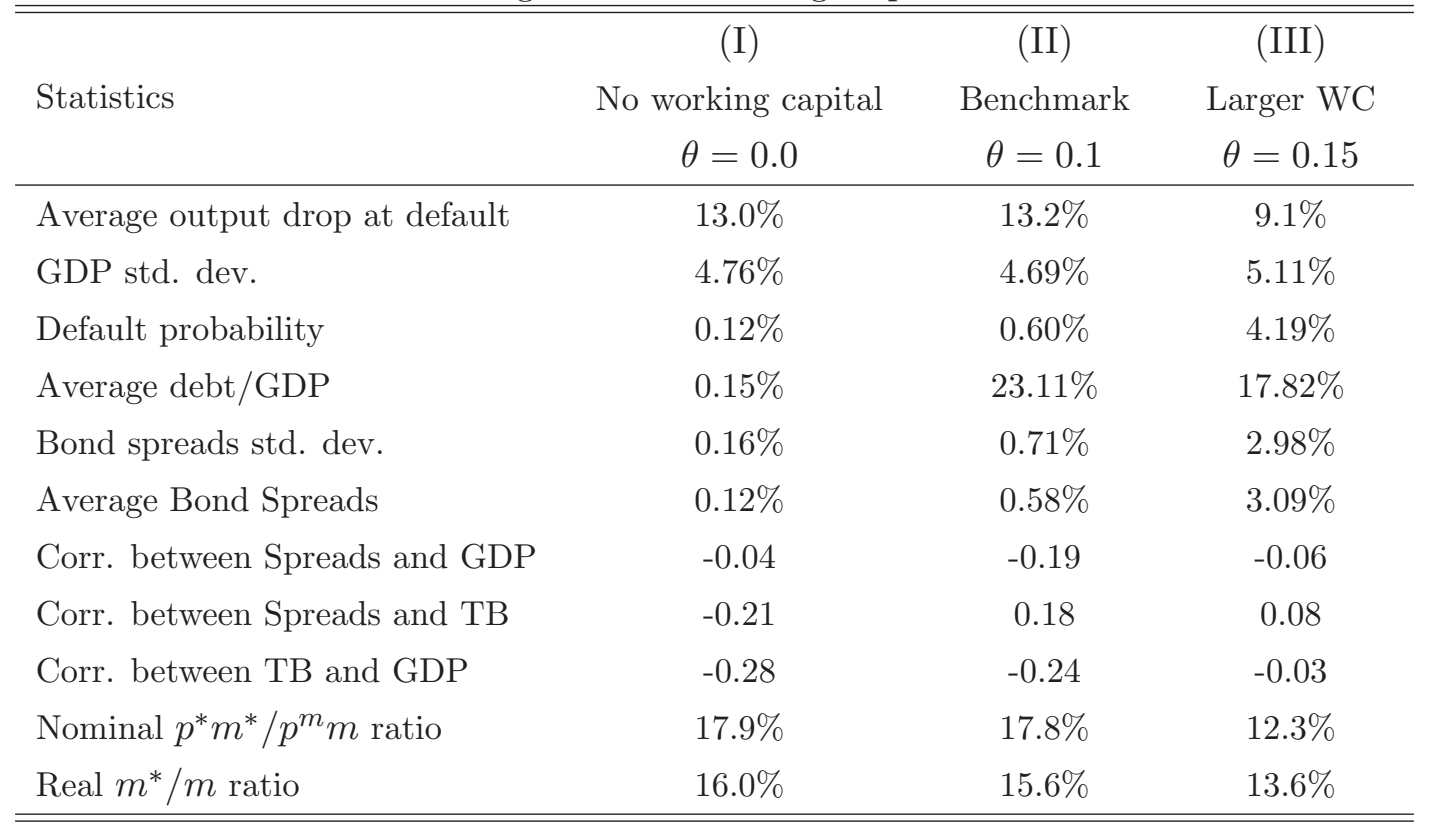

The left-side panel of Figure 10 compares default event windows for GDP in the benchmark model and in the model without working capital. The GDP drop at default is identical in the two cases by construction, since both models are calibrated to obtain the same 13 percent output loss at default. Before the default occurs, however, the two models produce significantly different dynamics. The benchmark model shows a gradual recession that starts 6 quarters before the default, while the model without working capital produces a sustained boom that peaks just before default hits, which is not in line with the data. This is because the model without working capital lacks an endogenous feedback mechanism from default risk to output, and default is preceded (on average) by positive TFP shocks. The recovery stage is nearly identical in both models, but this is also by construction because both cases are driven by the mean reversion of shocks targeted to produce GDP stochastic processes with identical characteristics. The benchmark model shows slightly higher output because of the possibility (with low probability) of credit-market re-entry, and the surge in output associated with this.

How sensitive are the model's results to the value of the working capital requirement beyond the extreme case of $\theta=0$ ? To answer this question, we report in Column (III) of Table 4 results for $\theta=0.15$, instead of 0.1 as in the benchmark case. The higher working capital coefficient reduces the mean debt ratio by 6 percentage points of GDP and generates a smaller output cost of default. In contrast, the variability of GDP, the probability of default, and the mean and standard deviation of spreads all increase sharply. 

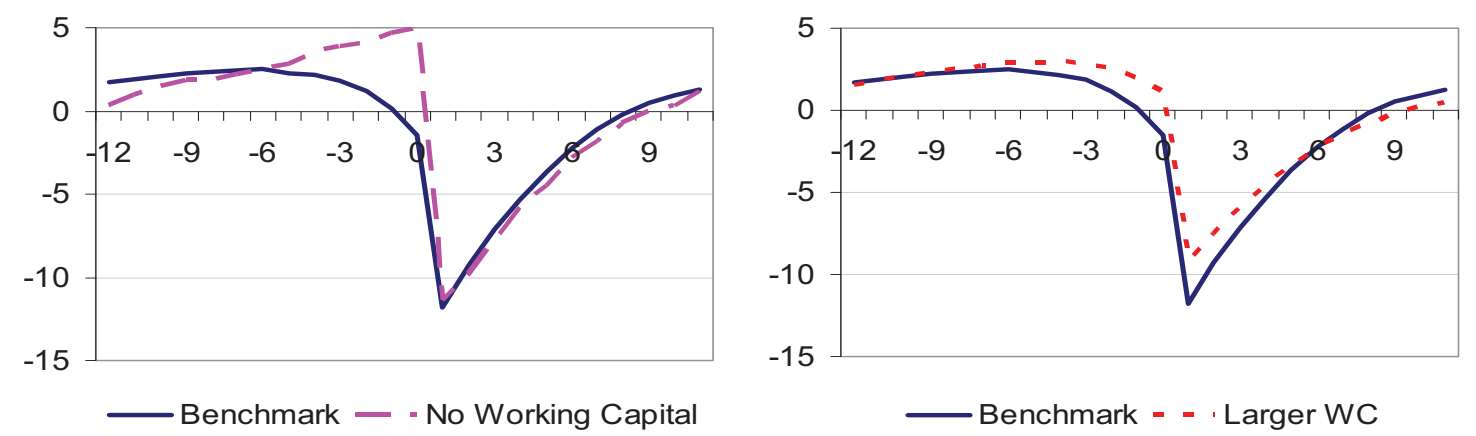

Figure 10: Comparison of Output Dynamics for Alternative Working Capital Specifications

These changes reflect the fact that the higher $\theta$ has opposing effects on default incentives and production plans. On one hand, since a larger fraction of imported inputs requires foreign financing to be purchased, changes in interest rates have a larger impact on production. This amplifies the response of output to productivity shocks, making output more volatile, in line with the findings of Neumeyer and Perri (2005) and Uribe and Yue (2006). On the other hand, default leads to a lower output cost of default on average because the TFP shock that triggers default is smaller with $\theta=0.15$ than in the benchmark case with $\theta=0.1$. Thus, the output levels before and after default are closer, generating a smaller output loss. At the same time, this lower output cost of default and the higher GDP variability make it optimal for the sovereign to exercise the default option more often, increasing the default probability and the volatility of bond spreads, and reducing the mean debt/GDP ratio.

The quantitative effects of tightening the working capital constraint on the debt/GDP ratio and on the default frequency are particularly large. Interestingly, we get these results even though average sovereign spreads, and hence the average interest rate on working capital, do not differ much from the one-percent risk free rate. In contrast, Neumeyer and Perri and Uribe and Yue obtain the result that working capital is important for emerging markets business cycles using average interest rates around 7 percent and $\theta=1$ (applied to the wages bill). Oviedo (2005) also showed that obtaining significant effects of working capital in the small open economy RBC model requires high values of $r^{*}$ and $\theta$.

The right-side panel of Figure 10 shows the output dynamics around default events for the benchmark model and the model with $\theta=0.15$. The model with the higher working capital coefficient still produces $\mathrm{V}$-shaped dynamics around defaults, but with a milder recession before default and a smaller drop in output at default, as explained above.

The distribution of defaults across "bad times" and "good times" also changes with the value of $\theta$. In particular, the higher $\theta$ shifts the distribution away from the states with larger output drops. At the annual frequency, we find that with $\theta=0.15$ about 12 percent of the defaults occur with output above trend, and 5 percent of them occur with GDP two standard deviations or more below trend (compared with 30 percent of defaults in the benchmark case). The correlation between GDP and default is about -0.27 . 


\subsection{Imperfect Substitution between Foreign and Domestic Inputs}

Column (I) of Table 5 reports simulation results reducing $\mu$ from 0.69 in the benchmark case to $\mu=0.5$. This reduces the Armington elasticity of substitution between $m$ and $m^{*}$ from 3.22 to 2 . Column (II) reproduces the results for the benchmark calibration. Column (III) reports results lowering the Armington weight $\lambda$ from the benchmark value of 0.61 to $\lambda=0.5$. All of the other parameters are the same as in the benchmark calibration.

\begin{tabular}{|c|c|c|c|}
\hline Statistics & $\begin{array}{c}(\mathrm{I}) \\
\text { Lower Elasticity } \\
\mu=0.5\end{array}$ & $\begin{array}{c}(\mathrm{II}) \\
\text { Benchmark } \\
\mu=0.69 \\
\lambda=0.61\end{array}$ & $\begin{array}{c}\quad(\mathrm{III}) \\
\text { Lower Weight } \\
\lambda=0.5\end{array}$ \\
\hline Average output drop at default & $25.1 \%$ & $13.2 \%$ & $16.9 \%$ \\
\hline GDP std. dev. & $4.95 \%$ & $4.69 \%$ & $5.43 \%$ \\
\hline Default probability & $0.02 \%$ & $0.60 \%$ & $0.19 \%$ \\
\hline Average debt/GDP & $168.59 \%$ & $23.11 \%$ & $92.36 \%$ \\
\hline Bond spreads std. dev. & $0.07 \%$ & $0.71 \%$ & $2.28 \%$ \\
\hline Average Bond Spreads & $0.02 \%$ & $0.58 \%$ & $0.12 \%$ \\
\hline Corr. between Spreads and GDP & -0.03 & -0.19 & -0.33 \\
\hline Corr. between Spreads and TB & 0.01 & 0.18 & 0.09 \\
\hline Corr. between TB and GDP & -0.29 & -0.24 & -0.37 \\
\hline Nominal $p^{*} m^{*} / p^{m} m$ ratio & $34.3 \%$ & $17.8 \%$ & $58.2 \%$ \\
\hline Real $m^{*} / m$ ratio & $29.2 \%$ & $15.6 \%$ & $46.2 \%$ \\
\hline
\end{tabular}

Table 5 shows that the values of $\mu$ and $\lambda$ affect significantly the magnitude of the output loss at default, as would be expected given the analysis of Section 3. With lower $\mu$ or $\lambda$, imported inputs are "more important" for final goods production. This is reflected in the nominal and real expenditure ratios of imported to domestic inputs, which are much higher with lower $\mu$ or lower $\lambda$ than in the benchmark case or in the Mexican data used as SMM targets in the calibration. On the other hand, these higher expenditure ratios are in the range of those for the countries included in the study by Goldberg and Campa (2006), so scenarios like those in Columns (I) and (III) of the Table should not be regarded as implausible.

When the Armington elasticity of substitution is lower, domestic inputs are poorer substitutes for imported inputs, and hence the efficiency loss of the $f$ sector when the economy defaults is bigger. Similarly, if domestic inputs have a lower $\lambda$, default is more painful when access to foreign inputs is lost. Accordingly, the output costs of default in the scenarios with lower $\mu$ and lower $\lambda$ reach about 25 and 17 percent respectively, compared with 13 percent in the benchmark. Because of these higher output costs of default, the probabilities of default 
are lower (0.02 and 0.19 percent respectively) and the mean debt ratios are much higher (169 and 92 percent respectively).

Changes in $\mu$ and $\lambda$ also affect business cycle comovements. Lower $\mu$ and lower $\lambda$ produce higher output variability. The standard deviations of GDP increase to 4.9 and 5.4 percent respectively, compared with 4.7 in the benchmark. The correlations of GDP with spreads and net exports remain negative, as in the benchmark case, but they are significantly more negative with $\lambda=0.5$.

Figure 11 shows the output dynamics around default episodes for the benchmark case and the cases with $\mu=0.5$ and $\lambda=0.5$. These alternative specifications preserve the Vshaped output dynamics. However, the scenario with $\mu=0.5$ produces a period of sustained expansion before defaults, instead of the gradual recession in the benchmark case, and a larger collapse in output when default occurs. The case with $\lambda=0.5$ yields a milder recession before default but again a larger output collapse at the time of default.

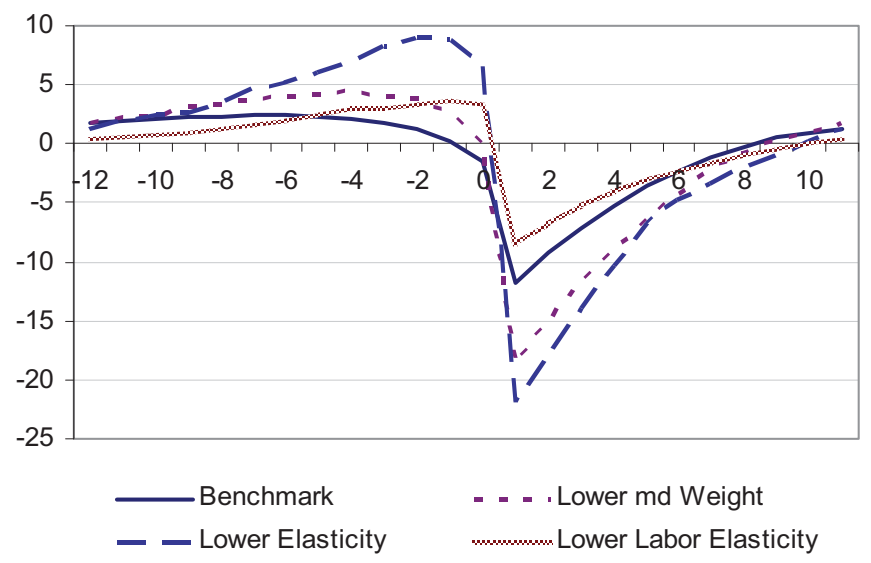

Figure 11: Comparison of Output Dynamics for Substitution Elasticity and Labor Elasticity

Increasing $\mu$ and $\lambda$ affects the distribution of default events across output realizations. Aggregating again to annual frequency, the fraction of defaults that occurs with output two standard deviations or more below trend falls to 16 percent with $\mu=0.5$, and rises to 37 percent with $\lambda=0.5$. The correlations between GDP and default events are -0.03 and -0.07 with $\mu=0.5$ and $\lambda=0.5$ respectively, compared with -0.12 in the baseline case.

\subsection{Labor Supply Elasticity}

Column (I) of Table 6 presents the results of a simulation rising $\omega$ from 1.45 in the benchmark to $\omega=2.0$, so that the labor supply elasticity falls from 2.2 to 1 . As demonstrated in Section 
3, a lower labor supply elasticity generates a lower output cost of default, without altering the slope of the relationship between default costs and TFP. Hence, the model with a less elastic labor supply supports less debt. At the same time, however, output variability declines, since labor variability is lower with the lower elasticity. The default probability falls, despite the lower default penalty, because the effects of the lower labor elasticity on default costs and output variability push in opposite directions: The lower output cost tends to increase the default frequency, but the lower output variability tends to reduce it. The bond spreads are lower and less volatile as well. The correlation between GDP and spreads rises, while net exports become more countercyclical. Also, in line with the results shown in Section 3, the expenditure ratios of imported to domestic inputs are not affected by changes in the labor supply elasticity.

Table 6: Changes in Elasticity of Labor Supply

\begin{tabular}{|c|c|c|}
\hline & $(\mathrm{I})$ & (II) \\
\hline Statistics & $\begin{array}{l}\text { Lower Elasticity } \\
\qquad \omega=2.0\end{array}$ & $\begin{array}{c}\text { Benchmark } \\
\omega=1.45\end{array}$ \\
\hline Average output drop at default & $11.5 \%$ & $13.2 \%$ \\
\hline GDP std. dev. & $3.45 \%$ & $4.69 \%$ \\
\hline Default probability & $0.14 \%$ & $0.60 \%$ \\
\hline Average debt/GDP & $22.87 \%$ & $23.11 \%$ \\
\hline Bond spreads std. dev. & $0.18 \%$ & $0.71 \%$ \\
\hline Average Bond Spreads & $0.15 \%$ & $0.58 \%$ \\
\hline Corr. between Spreads and GDP & -0.11 & -0.19 \\
\hline Corr. between Spreads and TB & 0.01 & 0.18 \\
\hline Corr. between TB and GDP & -0.34 & -0.24 \\
\hline Nominal $p^{*} m^{*} / p^{m} m$ ratio & $17.8 \%$ & $17.8 \%$ \\
\hline Real $m^{*} / m$ ratio & $15.6 \%$ & $15.6 \%$ \\
\hline
\end{tabular}

The output dynamics around default in the scenario with $\omega=2$ are again qualitatively consistent with the V-shaped pattern of the other scenarios (see Figure 12). Quantitatively, however, this scenario yields a period with a mild expansion before default, instead of recession, and a smaller output collapse when default takes place.

The change in labor elasticity also affects the distribution of default events across output realizations, but the effects are not as large as those caused by changing the Armington parameters. At annual frequency, the fraction of defaults with output below trend fell from 90 percent in the benchmark to 73 percent with $\omega=2$, and the fraction with output two standard deviations below trend fell from 30 to 6 percent. The correlation between output and defaults fell from -0.12 to -0.04 . 


\section{Conclusions}

This paper proposed a model of strategic sovereign default with endogenous output dynamics and examined its quantitative predictions. In the model, producers of final goods choose an optimal mix of imported and domestic inputs that are imperfect substitutes. Purchases of foreign inputs require foreign working capital financing, and production of domestic inputs requires reallocation of labor away from final goods production. In this setup, default causes an efficiency loss by forcing final goods producers to operate using only domestic inputs, and inducing labor to reallocate from the final goods sector to the sector producing domestic inputs. Lenders charge the same default risk premium on working capital loans as on sovereign debt because the sovereign diverts the repayment of working capital loans when the country defaults. This is in line with empirical evidence showing that corporate and sovereign interest rates are strongly correlated, and that in sovereign defaults since the 1980s Debt Crisis we often observe governments taking over the foreign obligations of private firms.

The model is consistent with three key stylized facts of sovereign debt: (1) the V-shaped dynamics of output around default events, (2) the negative correlation between interest rates on sovereign debt and output, and (3) the high debt-output ratios on average and when defaults take place. The model also replicates key emerging markets business cycle moments such as the countercyclical dynamics of net exports, the high variability of private consumption, the weakly negative correlation between defaults and GDP, and the correlations of intermediate goods with spreads and GDP.

The model produces an endogenous output cost of default that is increasing in the state of productivity. This result follows from the fact that the surge in the financing cost of working capital when default occurs makes it optimal for firms switch to domestic inputs, which are imperfect substitutes for foreign inputs, causing an efficiency loss. In turn, this efficiency loss is larger at higher levels of TFP because of the strong convexity of marginal products with Cobb-Douglas production. This endogenous increasing output cost of default is consistent with the shape of exogenous output costs that Arellano (2008) identified as useful in order to induce default incentives that trigger default in bad states of nature, at non-negligible debt ratios and at realistic default frequencies. In our model, however, the endogenous feedback between production and default produces a mean debt ratio four times larger than in Arellano's endowment economy model.

Our results also show that the model embodies a powerful financial amplification mechanism that can explain the seemingly large contribution of productivity shocks to output collapses during financial crises. In default episodes, this mechanism amplifies the output effect of TFP shocks by 80 percent. Solow residuals computed in the standard way overestimate the contribution of true TFP to the collapse of output when the economy defaults by about 70 percent.

Three features of the model are critical for the results: imported inputs require working 
capital, the government diverts the firms' working capital repayment when it defaults, and default induces an efficiency loss in production. Without the first two features, output would not respond to changes in country risk. On the other hand, the model would also fail if we rely "too much" on those two features: If exclusion from world credit markets implies that firms cannot buy foreign inputs and there are no domestic inputs available, or if the inputs are complements instead of substitutes, the output collapse and the associated cost of default would be unrealistically large (infinitely large if 100 percent of the cost of imported inputs requires payment in advance). In reality, firms in emerging economies facing financial crisis substitute foreign inputs with high financing costs for domestic inputs that can be employed at permissible financial terms, and/or look for alternative forms of financing using retained earnings or redirecting capital expenditures. The efficiency loss is also critical. Without it the working capital channel would not produce a sharp and sudden drop in output during periods of financial turmoil.

Our findings suggest that the model we proposed can provide a solution to the disconnect between sovereign debt models (which rely on exogenous output dynamics with particular properties to explain the stylized facts of sovereign debt) and models of emerging markets' business cycles (which assume an exogenous financing cost of working capital calibrated to match the interest rate on sovereign debt). We acknowledge, however, that the linkages between sovereign default and private sector borrowers, and the mechanisms by which default induces economy-wide efficiency losses, should be the subject of further research. For instance, introducing elements of political uncertainty, debt maturity, secondary debt markets, dynamic renegotiation, and risk averse lenders, all of which have been shown to add significant elements to the analysis of sovereign default in models with exogenous output dynamics, can be a very promising line of research (see, for example, Amador (2003), Benjamin and Wright (2008), Bi (2008a and 2008b), Broner, Martin and Ventura (2008), Chatterjee and Eyigungor (2008), Cuadra and Sapriza (2008), D'Erasmo (2008), and Lizarazo (2005)).

\section{References}

[1] Agca, Senay and Oya Celasun, 2009, "How Does Public External Debt Affect Corporate Borrowing Costs in Emerging Markets?" IMF Working Paper WP/09/266.

[2] Aguiar, Mark and Gita Gopinath, 2006, "Defaultable Debt, Interest Rates and the Current Account,", Journal of International Economics, 69(1), 64-83,

[3] Amador, Manuel, 2003, "A Political Economy Model of Sovereign Debt Repayment," mimeo, Department of Economics, Stanford University.

[4] Amiti, Mary and Jozef Konin, 2007, "Trade Liberalization, Intermediate Inputs, and Productivity: Evidence from Indonesia," American Economic Review, 97(5), 1611-1638. 
[5] Arellano, Cristina, 2008, "Default Risk and Income Fluctuations in Emerging Economies," American Economic Review, Vol 98 (3), 690-712.

[6] Arellano, Cristina and Narayana Kocherlakota, 2007, "Internal Debt Crises and Sovereign Defaults," Manuscript, University of Minnesota.

[7] Arteta, Carlos and Galina Hale, 2007, "Sovereign Debt Crises and Credit to the Private Sector," Journal of International Economics, Vol 74 (1), 53-69.

[8] Bai, Yan and Jing Zhang, 2006, "Financial Globalization and International Risk Sharing," Manuscript, University of Michigan and Arizona State University.

[9] Bi, Ran, 2008a, "Debt Dilution and the Maturity Structure of Sovereign Bonds," Ph.D. Dissertation, Department of Economics, University of Maryland.

[10] Bi, Ran, 2008b, "Beneficial Delays in Debt Restructuring Negotiations," Ph.D. Dissertation, Department of Economics, University of Maryland.

[11] Benjamin, David M. and Felipe Meza, 2007. "Total Factor Productivity and Labor Reallocation: the Case of the Korean 1997 Crisis," mimeo, Universidad Carlos III de Madrid.

[12] Benjamin, David and Mark L. J. Wright, 2008, "Recovery before Redemption: A Theory of Delays in Sovereign Debt Renegotiations," Manuscript, University of California - Los Angeles.

[13] Boughton, James M., 2001, "Silent Revolution: The International Monetary Fund 19791989," Ch. 9, IMF Publication.

[14] Broner, Fernado, Alberto Martin and Jaume Ventura, 2008, "Sovereign Risk and Secondary Markets," working paper, Department of Economics-CREI, Universitat Pompeu Fabra.

[15] Calvo, Guillermo A., Alejandro Izquierdo and Ernesto Talvi, 2006, "Phoenix Miracles in Emerging Markets: Recovering Without Credit form Systematic Financial Crises," NBER Working Paper 12101.

[16] Chatterjee, Satyajit and Burcu Eyigungor, 2008, "Maturity, Indebtedness, and Default Risk," Federal Reserve Bank of Philadelphia, Working Paper 09-2.

[17] Cuadra, Gabriel and Horacio Sapriza, 2007, "Fiscal Policy and Default Risk in Emerging Markets," Bank of Mexico Working Paper.

[18] Cuadra, Gabriel and Horacio Sapriza, 2008, "Sovereign Default, Interest Rates and Political Uncertainty in Emerging markets," Bank of Mexico Working Paper. 
[19] D'Erasmo, Pablo, 2008, “Government Reputation and Debt Repayment in Emerging Economies," Ph.D. Dissertation, Department of Economics, University of Texas-Austin.

[20] Eaton, Jonathan and Mark Gersovitz, 1981, "Debt with Potential Repudiation: Theoretical and Empirical Analysis," Review of Economic Studies, Vol 48(2), 289-309.

[21] Edwards, Sebastian, 1984, "LDC Foreign Borrowing and Default Risk: An Empirical Investigation, 1976-80," American Economic Review, Vol 74 (4), 726-734.

[22] Gelos, Gaston R., Ratna Sahay, Guido Sandleris, 2003, "Sovereign Borrowing by Developing Countries: What Determines Market Access?" IMF Working Paper.

[23] Goldberg, Linda S. and Jose Manuel Campa, 2006, "Distribution Margins, Imported Inputs, and the Insensitivity of the CPI to Exchange Rates," mimeo, Research Department, Federal Reserve Bank of New York.

[24] Gopinath, Gita, Oleg Itskhoki, and Roberto Rigobon, 2010, "Currency Choice and Exchange Rate Pass-through," American Economic Review, 100(1), 304-36.

[25] Halpern, Laszlo, Miklos Koren, and Adam Szeidl, 2009, "Imported Inputs and Productivity, , mimeo, University of California - Berkeley.

[26] Hatchondo, Juan Carlos and Leonardo Martinez, 2008, "Long-duration Bonds and Sovereign Defaults," Federal Reserve Bank of Richmond, Working Paper 08-2.

[27] International Monetary Fund, 2006, "World Economic Outlook - Financial Systems and Economic Cycles," September. Washington DC: International Monetary Fund.

[28] Kaletsky, Anatole, 1985, "The Costs of Default," New York: Twentieth Century Fund.

[29] Kohlscheen, Emanuel and S. A. O'Connell, 2008, "Trade Credit and Sovereign Debt," mimeo, Department of Economics, University of Warwick.

[30] Levy-Yeyati, Eduardo and Ugo Panizza, 2006, "The Elusive Cost of Sovereign Default," CIF Working Paper No. 11/2006.

[31] Lizarazo, Sandra Valentina, 2005, "Default Risk and Risk Averse International Investors," mimeo, Department of Economics, ITAM, Mexico.

[32] Martinez, Jose Vicente and Guido Sandleris, 2008, "Is it Punishment? Sovereign Defaults and the Decline in Trade," mimeo, Universidad Torcuato Di Tella.

[33] McDaniel, Christine A. and Edward J. Balistreri, 2002, "A Discussion on Armington Trade Substitution Elasticities," Office of Economics Working Paper, U.S. International Trade Commission, No. 2002-01-A. 
[34] Mendoza, Enrique G., 1991. "Real Business Cycles in a Small Open Economy". American Economic Review Vol 81(4), 797-818.

[35] Mendoza, Enrique G., 2010, "Sudden Stops, Financial Crises and Leverage: A Fisherian Deflation of Tobin's Q," American Economic Review, forthcoming.

[36] Meza, Felipe and Erwan Quintin, 2006, "Financial Crises and Total Factor Productivity," mimeo, Universidad Carlos III de Madrid.

[37] Neumeyer, Pablo. A. and Fabrizio Perri, 2005. "Business Cycles in Emerging Economies: The Role of Interest Rates," Journal of Monetary Economics, Vol 52, Issue 2, 345-380.

[38] Oviedo, Marcelo P., 2005, "World Interest Rate, Business Cycles, and Financial Intermediation in Small Open Economies," Manuscript, Iowa State University.

[39] Pitchford, Rohan and Mark L. J. Wright, 2008, "Holdout Creditors in Sovereign Debt Restructuring: A Theory of Negotiation in a Weak Contractual Environment,"

[40] Reinhart, Carmen. M, 2010, "This Time is Different Chartbook: Country Histories on Debt, Default, and Financial Crises," NBER Working Paper No. 15815.

[41] Reinhart, Carmen. M., and Kenneth S. Rogoff, 2010, "From Financial Crash to Debt Crisis," NBER Working Paper No. 15795.

[42] Reinhart, Carmen. M., Kenneth S. Rogoff and M. A. Savastano, 2003, "Debt Intolerance," NBER Working Paper No. 9908.

[43] Rose, Andrew K., 2005, "One Reason Countries Pay their Debts: Renegotiation and International Trade," Journal of Development Economics, v. 77, no. 1, pp. 189-206.

[44] Tomz, Michael and Mark Wright, 2007, "Do Countries Default in 'Bad Times'?", mimeo, Department of Economics, UCLA

[45] Uribe, Martin and Vivian Zhanwei Yue, 2006. "Country Spreads and Emerging Countries: Who Drives Whom?" Journal of International Economics, vol 69, 6-36.

[46] Wright, Mark L. J.,2006, "Private capital flows, capital controls, and default risk," Journal of International Economics, vol 69, 120-149.

[47] Yue, Vivian Zhanwei, 2010. "Sovereign Default and Debt Renegotiation," Journal of International Economics, 80 (2), 176-187. 


\section{Appendix}

\section{PROOF of THEOREM 1}

Given a productivity shock $\varepsilon$ and level of working capital loan $\kappa$, the utility from defaulting $v^{d}\left(\kappa, \varepsilon^{\prime}\right)$ is independent of $b$. We can also show that the utility from not defaulting $v^{n d}\left(b, \varepsilon^{\prime}\right)$ is increasing in $b_{t+1}$. Therefore, if $V\left(b^{1}, \kappa, \varepsilon^{\prime}\right)=v^{d}\left(\kappa, \varepsilon^{\prime}\right)$, then it must be the case that $V\left(b^{0}, \kappa, \varepsilon^{\prime}\right)=v^{d}\left(\kappa, \varepsilon^{\prime}\right)$. Hence, any $\varepsilon^{\prime}$ that belongs in $D\left(b^{1}, \varepsilon\right)$ must also belong in $D\left(b^{0}, \varepsilon\right)$.

Let $d^{*}\left(b, \varepsilon^{\prime}\right)$ be the equilibrium default decision rule. The equilibrium default probability is then given by

$$
p(b, \varepsilon)=\int d^{*}\left(b, \varepsilon^{\prime}\right) d \mu\left(\varepsilon^{\prime} \mid \varepsilon\right) .
$$

From $D\left(b^{1}, \varepsilon^{\prime}\right) \subseteq D\left(b^{0}, \varepsilon^{\prime}\right)$, if $d^{*}\left(b^{1}, \varepsilon^{\prime}\right)=1$, then $d^{*}\left(b^{0}, \varepsilon^{\prime}\right)=1$. Therefore,

$$
p\left(b^{0}, \varepsilon\right) \geq p\left(b^{1}, \varepsilon\right) .
$$

\section{PROOF of THEOREM 2}

From Theorem 1, given a productivity shock $\varepsilon$ and level of working capital loan $\kappa$, for $b^{0}<b^{1} \leq 0, p^{*}\left(b^{0}, \varepsilon\right) \geq p^{*}\left(b^{1}, \varepsilon\right)$. The equilibrium bond price is given by

$$
q\left(b^{\prime}, \varepsilon\right)=\frac{1-p\left(b^{\prime}, \varepsilon\right)}{1+r} .
$$

Hence, using Theorem 1, we obtain that:

$$
q\left(b^{0}, \varepsilon\right) \leq q\left(b^{1}, \varepsilon\right) .
$$

